\title{
Rad52 oligomeric N-terminal domain stabilizes Rad51 nucleoprotein filaments and contributes to their protection against Srs2
}

Emilie Ma', Laurent Maloisel' ${ }^{1}$ Léa Le Falher², Raphaël Guérois³, and Eric Coïc's?

1 Université de Paris and Université Paris-Saclay, Inserm, LGRM/iRCM/IBFJ CEA, UMR

Stabilité Génétique Cellules Souches et Radiations, F-92265, Fontenay-aux-Roses, France.

2 Present address: Precision Oncology Genomics, Oncology Therapeutic area, Sanofi R\&D, F94403 Vitry-Sur-Seine

3 CEA-Université Paris Saclay, DRF, i2BC, LBSR, Gif-sur-Yvette, 91191, France

Corresponding author: eric.coic@cea.fr 


\section{Abstract}

Homologous recombination (HR) depends on the formation of a nucleoprotein filament of the recombinase Rad51 to scan the genome and invade the homologous sequence used as template for DNA repair synthesis. Therefore, HR is highly accurate and crucial for genome stability. Rad51 filament formation is controlled by positive and negative factors. In Saccharomyces cerevisiae, the mediator protein $\operatorname{Rad} 52$ catalyzes Rad51 filament formation and stabilizes them, mostly by counteracting the disruptive activity of the translocase Srs2. Srs2 activity is essential to avoid the formation of toxic Rad51 filaments, as revealed by Srs2-deficient cells. We previously reported that Rad52 SUMOylation or mutations disrupting the Rad52-Rad51 interaction suppress $\operatorname{Rad51}$ filament toxicity because they disengage $\operatorname{Rad52}$ from $\operatorname{Rad} 51$ filaments and reduce their stability. Here, we found that mutations in Rad52 N-terminal domain also suppress the DNA damage sensitivity of Srs2-deficient cells. Structural studies showed that these mutations affect the Rad52 oligomeric ring structure. Overall, in vivo and in vitro analyzes of these mutants indicate that Rad52 ring structure is important for protecting Rad51 filaments from Srs2, but can increase Rad51 filament stability and toxicity in Srs2-deficient cells. This stabilization function is distinct from Rad52 mediator and annealing activities.

Keywords: Genome stability, DNA repair, Homologous Recombination, Rad52, Rad51, Srs2 


\section{Introduction}

Homologous recombination (HR) is an important pathway of DNA double-strand break (DSB) repair in all kingdoms of life. It is involved in DNA damage tolerance whereby stalled DNA replication forks that have encountered a DNA lesion can resume their progression [1,2]. HR also plays a central role in the correct segregation of homologous chromosomes in the first meiotic division [3], and is implicated in telomerase-independent alternative lengthening of telomeres by which cancer cells avoid telomer degradation [4]. HR uses a sequence homologous to the broken DNA, found preferentially on the sister chromatid or on the homologous chromosome, as a template for DNA repair synthesis [5]. Consequently, HR is a very accurate process. However, its ability to link DNA sequences scattered in the genome might promote genome instability. The two outcomes of repair by HR, gene conversion (GC) and crossing over (CO), are potential sources of important and sudden genetic changes, through rapid transfer of genetic information from one DNA sequence to another and also through genomic rearrangements, such as translocation or repeated sequence shuffling [6]. Additionally, DSB repair mechanisms associated with HR, such as break-induced replication and Single Strand Annealing (SSA), induce the loss of genetic information and can be at the origin of translocations $[1,6,7]$. Bacterial and yeast models allowed the identification of many control mechanisms to reduce the level of HR-associated genetic instability. For instance, the mismatch repair machinery suppresses heteroduplexes resulting from the interaction between divergent DNA sequences, thus avoiding GC and CO between DNA sequences scattered in the genome [8]. In yeast cells in vegetative growth, HR occurs more frequently through mechanisms that do not give rise to CO. Motor proteins such as Sgs1, Mph1 and Srs2, induce Synthesis-Dependent Strand Annealing (SDSA) by displacing the invading strand from the 
displacement-loops (D-loops) after DNA synthesis [9-13]. Sgs1, with its partners Top3 and Rmil, can also dissolve double Holliday junctions as non-CO products [14,15].

The formation of helical nucleoprotein filaments of Rad51/RecA family recombinases on single-stranded DNA (ssDNA) at the lesion site is a key step of HR. These proteins promote the search and strand invasion of a homologous DNA sequence required to initiate DNA repair synthesis $[2,16]$. In eukaryotes, this process is mediated by the RAD51 recombinase or by DMC1 for meiotic recombination. The formation of RAD51 filaments is tightly regulated to avoid the production of lethal HR intermediates. In yeast cells in vegetative growth, the formation of Rad51 nucleoprotein filaments requires mediator proteins to mobilize the ssDNA binding protein RPA, due to the lower affinity of $\operatorname{Rad} 51$ for ssDNA. $\operatorname{Rad} 52$ in yeast and BRCA2 in metazoans are among the most studied mediators of Rad51 filament formation [16]. $\operatorname{Rad} 51$ nucleoprotein filaments are formed in vitro by a two-step mechanism: nucleation of a Rad51 cluster on ssDNA, and cooperative filament growth [17-20]. Rad51 filament formation also requires Rad51 paralog activity (Rad55/Rad57 in S. cerevisiae, RAD51B, RAD51C, RAD51D, XRCC2 and XRCC3 in human cells, and the SHU complex in both), but they might have a more specific role during replication stress [21].

In yeast, Rad55/Rad57, the SHU complex, and Rad52 also counterbalance Rad51 filament disruption by Srs2 [22-27]. The reason for the regulation of Rad51 filament by positive and negative activities is not well understood, but it is essential to avoid, during $\mathrm{HR}$, the production of lethal intermediates and notably inappropriate Rad51 filaments that are toxic for the cell. The unproductive association of Rad51 with ssDNA might interfere with the normal progression of the DNA replication forks or with DNA repair events [28,29]. Massive Rad52 SUMOylation that leads to the dissociation of Rad52 and Rad51 from ssDNA [30], or Rad52 mutations disrupting the interaction between Rad52 and Rad51 suppress most of the Srs2-deficient cell phenotypes (e.g. DNA damaging agent sensitivity and synthetic lethality upon mutation of 
genes involved in DNA replication and repair) $[26,28]$. Rad55 $\Delta$ mutants also can suppress the DNA damaging agent sensitivity in $s r s 2 \Delta$ cells (Maloisel, L.; Ma, E.; Coïc E., in preparation). These findings indicate that the Rad52 and Rad55 mediator proteins are directly implicated in Rad51 filament toxicity. Specifically, they stabilize Rad51 filaments to protect them from Srs2 disruptive activity; however, they provide excessive stability to Rad51 filaments in Srs2deficient cells, thus interfering with other DNA transactions.

As Rad52 is essential at several steps of HR, the stabilization it confers can be observed only by studying separation of function mutations. Here, we describe mutations that are located in the conserved N-terminal domain of Rad52 and that suppress the Srs2-deficient cell phenotype without affecting Rad52 mediator activity. Rad52 N-terminal domain can bind to DNA and carries the catalytic domain for homologous ssDNA pairing [31]. It is also involved in the formation of Rad51 filaments because Rad52 C-terminus, which harbors the RPA and the Rad51 binding domains, is not sufficient for suppressing RPA inhibitory effect in Rad51 filament formation as efficiently as full length Rad52 [32]. To determine how the Rad52 Nterminal domain mutations suppress the Srs2-deficient cell phenotype we performed structural analyses. They suggested that such mutations affect the interaction between the oligomeric ring subunits formed by Rad52 N-terminal domain in solution [33-37]. In vivo and in vitro analyses of one of these mutations showed that it does not affect Rad52 mediator activity and only slightly its ssDNA binding and homologous ssDNA pairing activity. However, this mutation strongly reduces Rad52 protection of Rad51 filaments against Srs2 destabilization in vitro. These observations suggest that the Rad52 N-terminal domain integrity is important for Rad52 stabilization of Rad51 filaments and that this function is distinct from its mediator and annealing activities. 


\section{Results}

\section{Mutations affecting conserved residues of the N-terminal domain of Rad52 suppress Rad51 filament toxicity in Srs2-deficient cells}

Looking for RAD52 mutations that can suppress Srs2-deficient S. cerevisiae cells MMS sensitivity, we screened a $R A D 52$ random mutation plasmid library in cells lacking $R A D 52$ and SRS2 $(\operatorname{rad} 52 \Delta \operatorname{srs} 2 \Delta)$ exposed to methyl methanesulfonate at high dose (MMS, $0.015 \%)$. We found three mutations in conserved residues of Rad52 N-terminus: D79N, V95I and V129A (Figure S1). The nucleotide changes are listed in Table S2. We then inserted these mutations in a centromeric plasmid carrying a RAD52-FLAG allele for subsequent in vivo analysis by coimmunoprecipitation and chromatin immunoprecipitation (ChIP). Evaluation of resistance to MMS by spot assay of $\mathrm{rad} 52 \Delta \mathrm{srs} 2 \Delta$ cells transformed with these plasmids (Figure 1A) showed that each plasmid significantly restored MMS resistance in rad52 $\Delta$ srs $2 \Delta$ cells. We observed this suppressive effect also in $\gamma$-irradiated haploid cells where Srs2-deficient sensitivity was totally suppressed by rad52-V95I, rad52-V129A and rad52-D79N (Figure 1B).

We then tested their ability to suppress the synthetic sickness or lethality conferred by Srs2deficiency in cells in which different genes involved in DNA repair or replication (rad50 $\operatorname{rad} 54 \Delta, \operatorname{sgs} 1 \Delta, \operatorname{ctf} 18 \Delta, \operatorname{rrm} 3 \Delta$ or $m r c 1 \Delta$ ) had been depleted. These growth defects are attributed to the formation of toxic Rad51 filaments after the uncontrolled appearance of ssDNA generated by DNA repair or replication defects [28]. Analysis of the meiotic products of diploids resulting from crossing rad52-V95I srs $2 \Delta$ haploid cells with mutant cells showed that rad52-V95I suppressed all the synthetic phenotypes (Figure S2). 


\section{N-terminal Rad52 mutations that suppress Rad51 filament toxicity are proficient for HR in Srs2-deficient cells}

To measure the effect of N-terminal Rad52 mutations on Rad52 function, we transformed Rad52-deficient cells (but proficient for Srs2) with plasmids harboring the N-terminal RAD52 mutations. Rad52-V129A and rad52-D79N restored almost completely the resistance to genotoxic agents in rad52 $\Delta$ cells (Figure 1A-B). However, the rad52-V95I mutant did not fully rescue MMS sensitivity in rad52 $\Delta$ cells (Figure 1A), and it did not fully complement rad52 $\Delta$ cells for $\gamma$-ray survival, as indicated by the 4-fold survival reduction upon exposure to 400Gy compared with wild type (WT) cells (Figure 1B). Nevertheless, the survival rate of rad52-V95I cells was higher than that of Rad52-Rad51 interaction-defective rad52-Y376A cells and of Rad52-deficient cells [26]. The absence or relatively low $\gamma$-ray and MMS sensitivity of cells bearing the Rad52 N-terminal mutations suggests that they can form functional Rad51 filaments. This hypothesis was strengthened by the finding that SRS2 inactivation fully suppressed the $\gamma$-ray and MMS sensitivity of rad52-V95I cells (Figure 1A-B). Therefore, as observed for mutations that impair Rad52-Rad51 interaction, the sensitivity of rad52-V95I cells to genotoxic agents was not related to reduced Rad52 mediator activity, but was linked to Srs2 activity. Altogether, these results suggest that the Rad52 N-terminal domain stabilizes Rad51 filaments from Srs2 activity, in addition to providing toxicity in Srs2-deficient cells.

Other previously described N-terminal Rad52 mutations show a mild sensitivity to $\gamma$-irradiation [38]. This is notably the case for the rad52-R37A (initially referred to as rad52-R70A) mutation in Rad52 N-terminal DNA binding domain that abolishes the pairing reaction required to complete SDSA [39]. However, this mutation is more sensitive than the mutants we selected and cannot suppress the sensitivity of Srs2-deficient cells (Figure 1B). Therefore, the Rad52 Nterminal annealing activity does not appear to be the main factor of stability provided by Rad52. It is important to note that Srs2 deletion in rad52-R37A cells leads to a slight increase in cell 
viability, suggesting that the R37A mutation might affect Rad51 filament protection against Srs2.

\section{Gene conversion and SSA still occur in the Rad52 N-terminal mutants}

We then measured the rate of $\gamma$-ray-induced HR between $\arg 4-R V$ and $\arg 4-B g$ heteroalleles

(Figure 1C) in diploid cells that are homozygous for rad52-V95I and for rad52-D79N, one of the mutations that shows no sensitivity to $\gamma$-ray irradiation (Figure 1D). Rad52-V95I homozygous diploids were less sensitive to $\gamma$-ray irradiation than haploid cells. This might be the consequence of the expression of both mating-type alleles MATa and MAT $\alpha$ in diploid cells, which is known to compensate for ionizing radiation sensitivity associated with other mutations, such as $\operatorname{srs} 2 \Delta$ or $\operatorname{rad55\Delta }$ and $\operatorname{rad57\Delta }$ [40-42]. Rad52-D79N homozygous diploids were not sensitive to ionizing radiation, and HR frequencies were comparable in mutant and WT cells. However, HR was reduced by 2-3 times in rad52-V95I mutants, indicating that although HR still occurred in these cells, Rad51 filament stability or formation was weakened. Remarkably, the strong hyper-recombination phenotype associated with acute sensitivity to $\gamma$ ray of Srs2-deficient diploid cells was partially suppressed in the rad52-D79N and strongly suppressed in the rad52-V95I mutant, as observed with the Rad52-Rad51 interaction-defective rad52-Y376A mutant [26]. Indeed, rad52-V95I srs2 $\Delta$ homozygous diploid cells were 100 times more resistant than $s r s 2 \Delta$ cells to $400 \mathrm{~Gy}$, and HR frequency was 100-fold reduced (Figure 1D). This indicates that the Rad52 N-terminal domain is as important as its Rad51-binding domain for Rad51 filament stabilization.

We also measured the effect of both RAD52 mutants on DSB repair. To this aim, we used a genetic system that allows the repair of a DSB induced by the HO endonuclease at the MAT locus of haploid cells (chromosome III) by gene conversion using another MAT copy located on chromosome V (Figure 1E) [10]. We observed that the rad52-V95I and rad52-D79N 
mutations affected cell survival only marginally, confirming the formation of functional Rad51 filaments in these mutants. As observed before [10], DSB formation strongly reduced survival of Srs2-deficient cells because these cells cannot properly resolve displacement-loops through the SDSA pathway. The RAD52 mutants had only a marginal effect on survival of Srs2deficient cells, indicating that they cannot rescue the SDSA defect.

Finally, because the N-terminal domain is important for DNA binding and for catalyzing the pairing of homologous ssDNA required to perform SSA, we compared the capacity of rad52$V 95 I$, rad52-D79N and rad52-R37A cells to survive an inducible DSB that can be repaired by SSA between DNA repeats separated by $25 \mathrm{~kb}$ [43]. In this system, DSB repair is strictly dependent on RAD52. Rad52-V95I cells were not sensitive to DSB formation and therefore allowed repair by SSA (Figure $1 \mathrm{~F}$ ). In contrast, the rad52-R37A mutant (defective binding to ssDNA) showed a 5-fold reduction in cell survival after DSB formation. Srs2 is also essential to survive DSB formation in this system [43], a result we confirmed here. It has been proposed that Srs2 is required to remove Rad51 that accumulates on long 3'-ssDNA generated from DSB processing [29] and to avoid the formation of branched toxic joint molecules upon ssDNA invasion at ectopic positions [44]. We observed that the $\operatorname{srs} 2 \Delta$ phenotype was fully suppressed

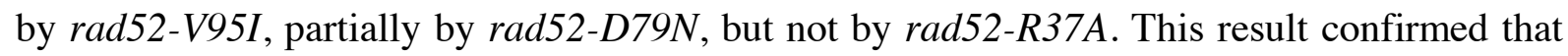
Rad52 N-terminus is involved in the toxicity of Rad51 filaments in Srs2-deficient cells, independently of ssDNA binding.

Structural analysis of the Rad52 N-terminal domain suggests that Rad52-V95I, rad52V129A and rad52-D79N affect Rad52 oligomerization

A model of the N-terminal domain of $S$. cerevisiae Rad52 could be obtained from the oligomeric structure of human Rad52 in its free [36] and bound to ssDNA [45] forms (PDB codes 1H2I and 5XRZ, respectively) (Figure 2A). The crystal structure of the human N-terminal 
Rad52 revealed a closed ring consisting of eleven monomers. Each monomer has a $\beta-\beta-\beta-\alpha$ fold, made of highly conserved amino acid residues. The subunit contacts involve interactions between $\beta$-strands, such that a continuous $\beta$-sheet extends around the entire molecule. Additional contacts are provided by the C-terminal helix that swaps across the domain boundary and interacts with an adjacent subunit [33,36]. Structural analysis of this model could be performed for each of the three residues mutated in the screen for $\operatorname{srs} 2 \Delta$ MMS-sensitivity suppressors (D79, V95 and V129, indicated as pink spheres on the cartoon representation of a monomer of yRad52; Figure 2B) and R37. The conservation map (Figure 2B, lower panel) showed that R37 was the most conserved position, while the other positions exhibited a less stringent conservation pattern in Rad52 homologs. A focus on V95 structural context (Figure 2C, upper left panel) highlighted that its sidechain is fully buried forming a well packed hydrophobic core with a network of hydrophobic sidechains. Mutation V95I could be tolerated assuming that neighboring sidechains adopted different rotameric states to accommodate the extra methyl group, with potential impact on more remote regions, such as those at the interface between Rad52 monomers. Moreover, the bulkier isoleucine residue in the mutant might induce an overpacking of the hydrophobic core that may reduce the intrinsic stability of the folded structure, as observed in other cases of substitutions in the core of folded domains [46]. To test the consequence of a more profound core disruption, we replaced V95 with other residues of different steric and chemical properties. V95T, which conserved the core geometry but reduced its hydrophobicity, behaved as WT Rad52 for MMS resistance and did not suppress the $\operatorname{srs} 2 \Delta$ mutant MMS sensitivity (Figure 3). Therefore, the slight distortion of the hydrophobic core is important to confer the suppressor phenotype. However, V95D and V95F, which probably disrupt the core, were as sensitive to MMS as rad52 $\Delta$ mutants and did not display any suppressor phenotype (Figure 3). On the other hand, D79 (Figure 2C, upper right panel) lies at the interface between Rad52 subunits and forms an intermolecular salt bridge with K117 in the 
neighboring subunit. By suppressing the charge complementarity, the D79N mutation may decrease the stability of the salt-bridge interaction, while maintaining the polar contact and bringing minimal steric perturbation. V129 is in contact with I106 in an adjacent Rad52 subunit and might contribute to the stability of the oligomeric Rad52 assembly. The mutation V129A might alter the stability of the inter-subunit Rad52-Rad52 interface by altering the intensity of the hydrophobic effect with neighboring residues. Altogether, a common feature shared by these three positions is that the mutated residues might affect the oligomeric assembly stability rather than directly disturb the interaction with ssDNA. The perturbation caused by each mutation could be of mild amplitude at the level of each individual monomer, but amplified by the oligomeric organization of Rad52, thus cumulating the impact of each monomer. Conversely, the sidechain of R37 contacts directly the phosphate backbone of the ssDNA molecule and this explains the deleterious effect of the R37A mutation on SSA activity.

Our structural studies suggest that Rad52-V95I could affect the oligomer stability. We monitored Rad52 intracellular levels during a cycloheximide expression shut-off experiment and found that the steady-state level of Rad52-V95I, but not of Rad52-D79N, -V129A and R37A, was lower than that of WT Rad52 (Figure 4A). Rad52-V95I stability in vitro was not different compared with WT Rad52 (Figure 4B), suggesting that the destabilization of the hydrophobic core by V95I in vivo is the result of increased sensitivity to proteasomal degradation.

As the structural study suggested that all three mutant suppressors affect Rad52 oligomeric organization, we focused on Rad52-V95I that has the strongest impact on Rad52 (Figure 1). First, we wanted to confirm our prediction that the V95I mutation affects Rad52 oligomeric structure. The observation of Rad52 in solution by Transmission Electronic Microscopy (TEM) confirmed that Rad52 formed ring-like structures in solution (Figure 5), as previously reported [35]. With WT Rad52, 90\% of the structures observed were well-shaped rings displaying a 
distinctive hole in the middle. Conversely, with Rad52-V95I only 75\% of rings had a hole, confirming that this mutation slightly destabilizes the ring organization. Surprisingly, we obtained similar results by incubating Rad52 with ssDNA. This effect was more pronounced when we added ssDNA to Rad52-V95I (only $47 \%$ of well-shaped rings). Therefore, ssDNA binding and the V95I mutation do not induce the same distortion on Rad52 rings. V95I does not seem to alter the interaction between Rad52 monomers because Rad52-V95I selfinteraction was not different compared with WT Rad52, as measured by quantitative two-hybrid screening (Y2H) assay (Figure S3).

\section{Rad52-V95I affects the N-terminal ssDNA binding domain, but does not impair Rad52 global DNA binding, and only marginally reduces pairing of RPA-coated ssDNA}

The structural analysis suggested that V95I might not deeply affect Rad52 binding to DNA. Additionally, our genetic analysis showed that it does not alter DSB repair by SSA, suggesting that DNA binding and DNA pairing are not profoundly affected. We used electrophoretic mobility shift assays (EMSA) to test this hypothesis. Purified WT Rad52 and Rad52-V95I (FLAG-tagged) bound similarly to ssDNA and dsDNA (Figure 6A). As Rad52 harbors two DNA binding domains, one in the $\mathrm{N}$-terminal and one in the C-terminal region [32], we asked whether DNA binding through the C-terminal DNA binding domain could hide an N-terminal binding default conferred by V95I. Therefore, we purified peptides encompassing the WT and V95I-mutated N-terminal domain (1-226), and tested DNA binding by EMSA. The V95I mutation affected both ssDNA and dsDNA binding (Figure 6B), but the mutated N-terminal peptide could still bind to DNA at low concentration $(0.05 \mu \mathrm{M})$, unlike the 1-326 peptide harboring the R37A mutation that cannot bind to ssDNA at $1 \mu \mathrm{M}$ [39]. Moreover, full length Rad52-V95I annealed complementary ssDNA strands as efficiently as WT (Figure 6C). Only when the ssDNA strands were coated with RPA, which slows down the reaction catalyzed by 
Rad52 [47], we observed a slight decrease ( $<1.5$ times) in the pairing efficiency by Rad52V95I. In comparison, R37A is totally defective [32].

\section{The V95I mutation reduces Rad52 interaction with Rad59, but does not impair interaction with RPA, Rad51, and Srs2}

The Rad52 N-terminal domain interacts with the Rad52 paralog $\operatorname{Rad59}$ [48], a protein that enhances Rad52 ssDNA annealing [49] and is important for SSA completion [50]. Coimmunoprecipitation experiments showed that compared with FLAG-tagged WT Rad52, the capacity of FLAG-tagged Rad52-V95I to co-immunoprecipitate MYC-tagged Rad59 was reduced by 2-fold (Figure 7A). Therefore, the destabilization of RAD52 oligomeric structure by the V95I mutation affects Rad59 binding. However, such instability was not strong enough to influence SSA. To rule out that the reduced interaction with Rad59 did not suppress MMS sensitivity in Srs2-deficient cells, we measured MMS resistance in rad59 $\Delta$ srs $2 \Delta$ cells (Figure S4). We observed high MMS sensitivity in rad59 $\Delta$ cells, similar to what observed after $\gamma$ irradiation [51]. However, $\operatorname{rad} 59 \Delta \operatorname{srs} 2 \Delta$ double mutants were more sensitive to MMS than single $\operatorname{rad} 59 \Delta$ and $\operatorname{srs} 2 \Delta$ single mutants, ruling out $\operatorname{rad} 59 \Delta$ role as suppressor.

As the rad52-V95I mutation and Rad52 mutations in which interaction with Rad51 is impaired can suppress Srs2-deficient cell phenotypes, we also quantified co-immunoprecipitation of Rad51 with Rad52-V95I-FLAG and WT Rad52-FLAG and we did not detect any difference (Figure 7B). Moreover, the V95I mutation did not affect interaction with RPA (Figure 7C). Finally, we used an $\mathrm{Y} 2 \mathrm{H}$ assay adapted from [52] to test the interaction between Rad52 and a peptide covering the 998-1174 C-terminal part of Srs2 (Figure 7D). We found that the V95I mutation did not change significantly binding to Srs2. 


\section{The V95I mutation does not affect Rad51 filament formation at a HO-induced DSB, but increases Rad51 filament disruption by Srs2}

Our data suggest that altering Rad52 oligomeric structure suppresses the potential toxicity of Rad51 filaments, but also induces the formation of Rad51 filaments that are more sensitive to destabilization by Srs2. This structure modification might have detectable consequences on Rad51 recruitment at DSB. Therefore, we measured the recruitment of proteins involved in Rad51 filament formation by ChIP in haploid cells that express WT or mutant Rad52-FLAG. We used the SSA system designed by Vaze et al. (2002) where a HO-induced DSB can be repaired by SSA between direct repeats located $25 \mathrm{~kb}$ apart. This assay involves the formation of long 3'-end ssDNA tails generated from the DSB, thus ensuring the sensitive detection of RPA, Rad52-FLAG and Rad51 recruitment to the DSB site. Quantitative PCR assays using primer sets that amplify DNA sequences at $0.6 \mathrm{~kb}$ or $7.6 \mathrm{~kb}$ upstream of the DSB site at different time points after DSB induction (Figure 8) showed an increase of the relative enrichment in RPA, Rad52-FLAG and Rad51 at the DSB site compared with the uncut ARG5,6 locus (blue) in WT cells. At 4 hours after DSB induction, RPA, Rad52-FLAG and Rad51 loading was lower at $7.6 \mathrm{~kb}$ (green) than at $0.6 \mathrm{~kb}$ (red), as described previously [26]. We also confirmed that Rad51 enrichment was higher in $\operatorname{srs} 2 \Delta$ than WT cells, particularly at $7.6 \mathrm{~kb}$, showing that Srs2 displaces Rad51 much more efficiently at distant sites [28].

In rad52-V95I-FLAG cells, RPA loading was not significantly changed, compared with Rad52FLAG cells. Conversely, Rad51 loading at $0.6 \mathrm{~kb}$ was reduced by 2.5 -fold. This could be interpreted as a deficiency of Rad52 mediator activity. However, in rad52-V95I-FLAG srs $2 \Delta$ cells, Rad51 loading was 2.8- and 5.5-fold higher than in rad52-V95I-FLAG cells at $0.6 \mathrm{~kb}$ and $7.7 \mathrm{~kb}$ respectively, as observed in $\operatorname{srs} 2 \Delta$ cells. Therefore, the reduction in Rad51 loading in rad52-V95I-FLAG cells fully depends on Srs2 activity. We previously obtained similar results with Rad52 mutants that impair Rad52-Rad51 interaction [26]. Rad52-V95I-FLAG recruitment 
also decreased by 1.7-fold compared with WT, and was significantly increased by 1.3 in Srs2deficient cells. Altogether, these results suggested that the Rad52 N-terminal domain integrity is essential to prevent $\operatorname{Rad} 51$ and Rad52 disassembly by Srs2.

We performed the same experiment also in rad52-R37A cells. Surprisingly, we observed a 3.3fold decrease in Rad51 recruitment at $0.6 \mathrm{~kb}$, which was Srs2-dependent because Rad51 loading was increased by 2.9 -fold in Srs2-deficient cells at this locus. Rad52-R37A-FLAG loading was reduced by 2.6-fold compared with WT. Besides the defect in ssDNA pairing and SSA, Rad52R37A also is defective for Rad51 filament protection. As rad52-V95I impairs only Rad51 protection, we concluded that the Rad51 filament protection function can be separated from the ssDNA pairing activity.

\section{The V95I mutation abrogates RPA-mediated inhibition of Rad51 filament formation in vitro}

We then used electron microscopy (EM) to determine the effect of Rad52-V95I on Rad51 filament formation on $5 \mathrm{~kb}$-long $\phi X 174$ viral (+) ssDNA (Figure 9A). As described before (reviewed in [53]), RPA addition to ssDNA prior to the addition of Rad51 inhibits complete Rad51 filament formation, as we previously confirmed [26]. Here, we found that only $24 \%$ of complete Rad51 filaments were formed in this condition. The concomitant addition of Rad52 and Rad51 to RPA-coated ssDNA allowed increasing the percentage of complete $\operatorname{Rad} 51$ filaments to 78\%, confirming that Rad52 overcomes RPA inhibitory effect. Addition of Rad52V95I, instead of Rad52, to RPA-coated ssDNA also led to the same percentage of complete Rad51 filaments, showing that Rad52-V95I is as efficient as WT Rad52 to overcome RPA inhibition.

These experiments confirmed our previous observation that Rad52 remains associated with Rad51 filaments (Figure 9B) [26,28]. Rad52-V95I also remained associated with Rad51 
filaments (Figure 9B). The median distribution of Rad52 and Rad52-V95I associated with

Rad51 filaments was the same (1), indicating that the mutation does not modify $\operatorname{Rad} 52$ association with $\operatorname{Rad} 51$ filaments.

Next, we asked whether Rad52-V95I-catalyzed Rad51 filaments were efficient for strand exchange in an in vitro $\phi X 174-$ based assay (Figure 9C). As previously described, RPA prebound to ssDNA reduced strand exchange by approximately 1.8 -fold compared with the standard reaction, where Rad51 is added prior to RPA. The concomitant addition of Rad52 and Rad51 released the inhibition by pre-bound RPA, and led to a 1.6-fold increase in strand exchange. We found that Rad52-V95I could release the RPA inhibition as efficiently as WT Rad52, confirming that destabilization of the Rad52 N-terminal domain does not affect Rad51 filament formation and that these filaments are functional.

Our genetic data and ChIP analysis suggested that V95I affects Rad51 filament protection by Rad52 against Srs2 dismantling activity. We previously reported that this protection could be seen in vitro by EM [26]. Therefore, we assembled Rad51 filaments in vitro on $\Phi$ X174 ssDNA with WT Rad52 or Rad52-V95I, and then incubated them with Srs2 for 5 minutes (Figure 9D). When Rad52 and Rad51 were added together on RPA-coated ssDNA, about $70 \%$ of complete Rad52-associated Rad51 filaments were still present after 5 minutes of incubation with Srs2. This protection was clearly weakened when Rad51 filaments were formed with Rad52-V95I because we observed only 30\% of complete Rad51 filaments after addition of $\operatorname{Srs} 2$.

\section{Rad52-V95I does not destabilize Rad51 filaments in a competition assay}

Finally, we tested whether Rad52-V95I could challenge the stability of Rad51 filaments by incubation with excess ssDNA ( $\Phi$ X174 viral (+) strand). We formed Rad51 filaments by adding Rad51 with WT Rad52 or Rad52-V95I on a 400 nt-long or 1500 nt-long Cy5-labeled ssDNA 
bioRxiv preprint doi: https://doi.org/10.1101/2021.05.18.444666; this version posted May 21,2021 . The copyright holder for this preprint

(which was not certified by peer review) is the author/funder, who has granted bioRxiv a license to display the preprint in perpetuity. It is made available under aCC-BY-NC-ND 4.0 International license.

pre-coated with RPA. We used the previously described optimal stoichiometric conditions, with slight modifications [28] (see Material and Methods). Analysis of glutaraldehyde-fixed protein complexes by agarose gel electrophoresis confirmed that Rad52-V95I assembled Rad51 filaments as efficiently as WT Rad52 (Figure S5). After incubation at $37^{\circ} \mathrm{C}$ for 20 minutes to allow Rad51 filament formation, we added the competing $\Phi$ X174 viral (+) strand to the reaction for 30 minutes. The stability of Rad51 filaments assembled with Rad52 or Rad52-V95I was comparable, indicating that Rad51 filament toxicity probably requires additional factors in vivo. 


\section{Discussion}

\section{Rad52 N-terminal domain integrity is required for Rad51 filament stability}

In a previous study, we reported that independently of its crucial function in Rad51 filament formation, Rad52 is responsible for HR toxicity in cells that does not express Srs2, the negative regulator of HR [28]. To obtain more insight into Rad52 contribution to Rad51 filament structure and potential toxicity, we then screened a $R A D 52$ random library for mutations that suppress the MMS sensitivity of Srs2-deficient cells without affecting the Rad51 filament mediator activity. We found that disrupting the Rad52-Rad51 interaction leads to the suppression of Srs2-deficient cell phenotypes. Here, we describe other mutations located in the conserved N-terminal domain of Rad52 that also can suppress the Srs2-deficient cell phenotype. Like the Rad52-Rad51 interaction mutants, these new mutants can suppress a broad range of $s r s 2_{-}$phenotypes attributed to the formation of toxic Rad51 filaments: MMS and $\gamma$-ray sensitivity in haploid cells, SSA deficiency and synthetic lethality with genes involved in DNA repair or DNA replication [28]. Therefore, losing the Rad52-Rad51 interaction or mutations in the Rad52 N-terminal domain alleviate the toxicity of Rad51 filaments in Srs2-deficient cells. Additionally, the RAD52 N-terminal mutations marginally suppress the $s r s 2$ _ deficiency in HOinduced ectopic gene conversion, like the Rad52-Rad51 interaction mutants. These phenotypes are probably related to Srs2 post-synaptic deficiency [28]. Therefore, the Rad52 N-terminal domain is directly responsible for the toxicity of pre-synaptic Rad51 filaments in Srs2-deficient cells. Mutations in this domain also displayed defects that are the direct consequence of Srs2 activity. The Srs2-dependent $\gamma$-ray sensitivity and Rad51 binding reduction close to a HOinduced DSB, as observed by ChIP in rad52-V95I cells, show that this mutation makes Rad51 filaments more sensitive to displacement by Srs2. Altogether, these results indicate that the Rad52 N-terminal domain stabilizes Rad51 filaments. Our present and previous results suggest 
a model in which Rad52 N-terminal domain stabilizes Rad51 filaments by remaining associated with Rad51 filaments through direct interaction with Rad51. Mutations impairing the Rad52Rad51 interaction and mutations that affect the oligomer stability can bypass the requirement of Srs2 to resist genotoxic agents, while the mutated Rad52 protein still catalyzes the formation of Rad51 filaments [26] and present results). $\operatorname{Rad52}$ stabilizes and protect $\operatorname{Rad51}$ filaments, making them toxic in the absence of Srs2 activity, probably because they are too stable to be rapidly removed to allow HR progression or the intervention of other DNA repair pathways $[54,55]$. On the other hand, Rad52 SUMOylation, which triggers the dissociation of Rad52 and Rad51 from DNA [30], can suppress this protection. As Rad52 is essential at several steps of HR, its different effects on Rad51 can be observed only by studying separation of function mutations.

\section{Rad52-dependent stabilization of Rad51 filaments can be separated from ssDNA binding and homologous ssDNA pairing activities}

The different phenotypes conferred by the V95I and R37A mutations suggest that stabilization of Rad51 filaments can be separated from homologous ssDNA paring and Rad52 mediator activity.

Our genetic analysis showed that the mutations V129A, D79N and V95I only affect Rad52 capacity to stabilize Rad51 filaments. Our structural analysis suggests that V129 and D79 are located at the interface between each Rad52 monomer and that they are important for the oligomer correct assembly (Figure 2). V95 is fully buried forming a well packed hydrophobic core with a network of hydrophobic sidechains. Mutation V95I has a potential impact on more remote regions, such as those at the interface between Rad52 monomers. Our EM analysis confirmed that V95I disturbs the correct assembly of Rad52 rings (Figure 5). This mutation also increases Rad52 sensitivity to proteasomal degradation (Figure 4). This observation can 
explain the strongest phenotype of the V95I mutation observed in $\gamma$-irradiated cells compared with V129A and D79N (Figure 1A and B). However, the V129A, D79N and V95I mutations do not affect SSA, indicating that they do not alter Rad52 ssDNA pairing activity (Figure 1F). Moreover, their capacity to repair a DSB shows that they do not affect gene conversion (Figure 1E). Additionally, the V95I mutation does not modify Rad52 capacity to form Rad51 filaments on RPA-covered ssDNA, as observed by ChIP in vivo (Figure 8) and by EM in vitro (Figure 9). However, the Srs2-dependent $\gamma$-ray sensitivity (Figure 1) and lower recruitment of Rad51 observed by ChIP (Figure 8) indicate that rad52-V95I reduces the protection of Rad51 filaments, as confirmed in vitro (Figure 9). Surprisingly, ChIP experiments showed that rad52$R 37 A$ also displays a weaker protection of Rad51 filaments in vivo, while it allows the normal recruitment of Rad51 filaments at a DSB (Figure 8). However, unlike the V129A, D79N and V95I mutations, rad52-R37A cannot suppress Srs2-dependent $\gamma$-ray sensitivity (Figure 1). This might be related to its default in ssDNA binding and pairing activity [39], making it unable to suppress the Srs2-deficient cell phenotype. Rad59 also could be involved in the protection of Rad51 filaments in conjunction with Rad52, but its strong sensitivity to genotoxic agents might hide this activity, like for rad52-R37A. The Rad52 N-terminal mutants we selected display a novel separation of function that allowed us to unravel the role of this domain in Rad51 filament stabilization and protection against Srs2.

\section{How does Rad52 stabilize Rad51 filaments?}

Rad52 clearly provides stabilization of Rad51 filaments independently of its mediator activity in vivo. Although we did not see any effect of the rad52-V95I mutation on Rad51 filament stability in a ssDNA competition assay in vitro, as we previously reported for loss of Rad52Rad51 interaction mutations [26], it is clear that these mutations suppress Rad51 filament toxicity and rescue most of the phenotypes of Srs2-deficient haploids cells. The toxic effect of 
bioRxiv preprint doi: https://doi.org/10.1101/2021.05.18.444666; this version posted May $21,2021$. The copyright holder for this preprint

(which was not certified by peer review) is the author/funder, who has granted bioRxiv a license to display the preprint in perpetuity. It is made available under aCC-BY-NC-ND 4.0 International license.

Rad52 binding to Rad51 filaments in vivo might require the association with the yeast Rad51 paralogs Rad55/Rad57 and the SHU complex, because they act as a functional ensemble with Rad52 [56]. Rad52 ring structure could participate in Rad51 filament stabilization through the interaction with Rad51 paralog complexes. It might also provide stability by holding a Rad51 focus on DNA, allowing Rad51 filaments to grow efficiently, as observed for BRC-2 in Caenorhabditis elegans in vitro [17].

Rad52 N-terminal domain also inhibits Rad51 filament removal from ssDNA by Srs2. It has been proposed that $\operatorname{Rad} 55 / \operatorname{Rad} 57$ and the SHU complex also protect $\operatorname{Rad} 51$ filaments from Srs2 activity [22,25]. Rad52 N-terminal domain could counteract Srs2 through a roadblock mechanism, as proposed for the Rad55/Rad57 complex [25]. It could also hold a stable Rad51 nucleus on ssDNA that can provide Rad51 filaments elongation despite of Srs2 activity. 


\section{Materials and methods}

\section{S. cerevisiae strains}

Strains used in this study are listed in Table S1. Experiments were mostly carried out in the FF18733 background. Diploid cells used in survival and recombination assays were the result of crosses between isogenic haploid strains bearing the arg4-RV and arg4-Bg frame-shift mutations. Plasmids bearing the mutations rad52-V95I, -V129A, -D79N, isolated from the random library [26], and $r a d 52-R 37 A$ were introduced in $\operatorname{rad} 52 \Delta$ or $\operatorname{rad} 52 \Delta \operatorname{srs} 2 \Delta$ cells (MMS experiments). RAD52-3His-6FLAG fusion proteins in YCplac111 plasmids with these mutations were also used ( $\gamma$-irradiation experiments and co-immunoprecipitation experiments). The mutations rad52-V95I, rad52-D79N and rad52-R37A were also introduced in the genome of yeast cells with the pop-in pop-out technique using the integrative plasmids Yiplac211rad52-V95I, Yiplac211-rad52-D79N and Yiplac211-rad52-R37A (gene conversion, SSA, ChIP).

\section{Directed mutagenesis}

Single mutations were introduced using a PCR method adapted from [57] in Yiplac211 or Ycplac111 plasmids containing the RAD52 gene with or without a C-terminal 6His-3FLAG tag.

\section{Sequence alignment}

Homologous sequences of $S$. cerevisiae $\operatorname{Rad} 52$ were retrieved using PSI-Blast searches against the nr database $[58,59]$. The full-length sequences of these homologs were aligned using the MAFFT software [60]. The final alignment was represented using Jalview [61]. 


\section{Irradiation and measurement of recombination rates}

$\gamma$-ray irradiation was performed using a ${ }^{13} \mathrm{Cs}$ source. After irradiation, exponentially growing cells were plated at the appropriate dilution on rich medium (YPD) to measure the survival rate, and on synthetic plates without arginine to quantify the number of HR events. The mean percentage of survival from at least three independent experiments is presented.

\section{Survival following DNA DSB formation}

Cells were grown overnight in liquid culture medium containing lactate before plating. Survival following HO-induced DNA DSB was measured as the number of cells growing on galactose-containing medium divided by the number of colonies growing on YPD. The presented results are the mean of at least three independent experiments.

\section{Structure}

The structural model of the Rad52 11-mer was generated using the SWISSMODEL server [62] based on the template of human RAD52 (PDB code: 5xrz) that shares $47 \%$ of identity. Conservation was calculated using the multiple sequence alignment of the Rad52 N-terminal domain and the rate4site algorithm [63]. Structure are represented using PyMOL (The PyMOL Molecular Graphics System, Version 2.0 Schrödinger, LLC.).

\section{Cycloheximide expression shut-off experiment}

Cultures grown in YPD medium overnight, were diluted to an $\mathrm{OD}_{6 ю}$ value of 0.2 in $30 \mathrm{ml}$ of fresh medium. Cultures were grown at $30^{\circ} \mathrm{C}$ to a $\mathrm{OD}_{\sigma \infty}$ value of 0.2 and a $2-\mathrm{ml}$ fraction was removed at the $0 \mathrm{hr}$ time-point. Then, cycloheximide (Sigma) was added to a final concentration of $50 \mathrm{ng} / \mu 1$. For each time-point, OD at $600 \mathrm{~nm}$ was measured and a 2-ml fraction was removed. Cell lysis was performed immediately after centrifugation by adding $50 \mu 1$ of SDS Buffer 
(50 mM Tris- $\mathrm{HCl}$ pH 7.5, 5\% SDS, 2.5\% glycerol, 50 mM DTT, 5 mM EDTA, 1 x Complete Protease inhibitor cocktail (Roche), bromophenol blue), and boiled at $95^{\circ} \mathrm{C}$ for 5 minutes. Proteins were separated on SDS-PAGE and transferred to a PVDF membrane. Rad52 was detected with a mouse anti-FLAG monoclonal antibody (Sigma, 1/10,000) followed by a monoclonal goat anti-mouse IR800 secondary antibody (1/10,000, Advansta)

\section{Y2H assay}

pBTM116 plasmids carrying RAD52 (WT or V95I) conjugated with LexA-DBD and pACT2 plasmids carrying RAD52 (WT or V95I) conjugated with Gal4-AD were transformed in TLM285 cells. pBTM116 plasmids carrying RAD52 (WT or V95I) conjugated with LexA-DBD and pACT2 plasmids carrying SRS2 998-1174 C-terminus conjugated with Gal4-AD were transformed in CTY10-5d cells. Transformants were selected in Synthetic medium without tryptophan and leucine. $\beta$-galactosidase activity was measured with the Yeast $\beta$-Galactosidase Assay kit (Thermo Fisher).

\section{Co-immunoprecipitation}

Yeast cells were grown in YPD medium to a concentration of $2.5 \times 10^{\circ}$ cells $/ \mathrm{ml}$. Cells were harvested and washed twice with PBS. Extracts were prepared as previously described [64]. Rad52-Rad51 were co-immunoprecipitated as described in [26] and Rad52-RPA and Rad52Rad59 as described in [28]. Whole-cell extracts $(1 \mathrm{mg})$ were incubated $\left(4^{\circ} \mathrm{C}\right.$ for 1 hour $)$ with $0.12 \mu 1$ of anti-Rad51 polyclonal antibody (Abcam) for Rad51 immunoprecipitation or with $1 \mu \mathrm{g}$ of anti-FLAG monoclonal (Sigma) for Rad52 immunoprecipitation. Then, $50 \mu 1$ of Dynabeads coupled to Protein A or Dynabeads Pan mouse IgG (Santa Cruz Biotechnology) were added, and the incubation continued for another hour. Immunoprecipitates were washed twice with $1 \mathrm{ml}$ of lysis buffer and resuspended in $30 \mu 1$ of Laemmli buffer $(1 \mathrm{x})$. For Rad52- 
Rad59 co-immunoprecipitation, elution was performed with $50 \mu \mathrm{g}$ of 3XFLAG peptide to avoid elution of the anti-FLAG antibody, which migrate at the same level as Rad59. The eluted proteins were analyzed by western blotting. Proteins were separated on $10 \%$ SDS PAGE and transferred to PVDF membranes. Proteins were detected with mouse anti-FLAG monoclonal (Sigma, 1/10000), rabbit anti-Rad51 polyclonal (Abcam, 1/2000), rabbit anti-RPA polyclonal (a gift from V. Géli, 1/2500), or mouse anti-MYC 9E10 monoclonal (Sigma, 1/1000) antibodies. Blots were then incubated with monoclonal goat anti-mouse IR800 or goat antirabbit IR700 or IR800 secondary antibodies (1/10000, Advansta). Protein-antibody complexes were visualized using the Odyssey CLx system (Li-cor Biosciences). The presence of Rad51 in the immunoprecipitated fractions could not be detected to validate the efficiency of the immunoprecipitation because it migrates at the same level as the anti-Rad51 IgG. However, the absence of Rad52 in the rad51 $\Delta$ immunoprecipitates confirmed that the detected Rad52-FLAG signals were related to the Rad52-Rad51 interaction.

\section{ChIP experiments and quantitative PCR analyses}

Cells were grown in YPD until late exponential phase. After inoculation in $400 \mathrm{ml}$ of YPLactate, cultures were grown to a concentration of 5 to $10 \times 10^{\circ}$ cells $/ \mathrm{ml}$. A $50-\mathrm{ml}$ fraction was removed at the 0 -hour time-point, and then galactose was added to a final concentration of $2 \%$. Incubation was continued and 50-ml fractions were removed at different time-points. Cells were fixed in $1 \%$ formaldehyde, which was then neutralized with $125 \mathrm{mM}$ glycine. Cells were centrifuged and washed with TBS buffer (20 mM Tris pH8, $150 \mathrm{mM} \mathrm{NaCl})$. Cell pellets were then frozen at $-20^{\circ} \mathrm{C}$. ChIP was carried out as previously described [26]. 


\section{Protein purification}

Rad52-FLAG, Rad52-V95I-FLAG, RPA, Rad51 and His-tagged Srs2 (N-terminal) were purified as in [26].

The Rad52-1-226 fragment, with or without the V95I mutation, was cloned in pCDF-hisSUMO plasmid by SLIC [65]. Rad52-1-226 was purified from E. coli BL21 (DE3) cells. Cells were grown in 1 liter of LB broth with $50 \mu \mathrm{g} / \mathrm{ml}$ spectinomycin at $37^{\circ} \mathrm{C}$ until $\mathrm{A}_{600}=0.8$. Protein expression was induced by addition of $0.5 \mathrm{mM} \mathrm{IPTG}$ followed by incubation at $37^{\circ} \mathrm{C}$ for 4 hours. Cells were lysed by sonication in $20 \mathrm{mM}$ Tris-HCL pH 7.5, $500 \mathrm{mM} \mathrm{NaCl}, 1 \mathrm{mM}$ DTT, $1 \mathrm{mM}$ AEBSF, $10 \mathrm{mM}$ benzamidine, $2 \mu \mathrm{M}$ pepstatin, $2 \mu \mathrm{M}$ leupeptin, $1 \mathrm{mg} / \mathrm{ml}$ lysozyme, and $0.1 \%$ NP40. Lysates were clarified by centrifugation and incubated with $20 \mathrm{mM}$ imidazole on Ni Sepharose High Performance Resin (GE Healthcare) at $4^{\circ} \mathrm{C}$ for 4 hours. The resin was washed with buffer $\mathrm{W} 1(20 \mathrm{mM}$ Tris $\mathrm{HCl}$ pH 7.5, $500 \mathrm{mM} \mathrm{NaCl}, 20 \mathrm{mM}$ imidazole, $10 \%$ glycerol, $0.5 \% \mathrm{NP} 40)$, and then with buffer W2 $\left(20 \mathrm{mM}\right.$ Tris $\mathrm{HCl} \mathrm{pH} 7.5$ at $4^{\circ} \mathrm{C}, 100 \mathrm{mM}$ $\mathrm{NaCl}, 20 \mathrm{mM}$ imidazole, 10\% glycerol, $1 \mathrm{mM}$ DTT). The His-SUMO tag was cut by addition of SUMO-protease at $4^{\circ} \mathrm{C}$ overnight. The Flow-Through was loaded in a $1 \mathrm{ml}$ RESOURCE S column (GE Healthcare), and eluted through a $25 \mathrm{ml}$ gradient (100 mM-1 M NaCl), in buffer Tris-HCl pH 7.5, 1 mM DTT. The Rad52-1-226-containing fractions were pooled, diluted to a final concentration of $150 \mathrm{mM} \mathrm{NaCl}$, and glycerol was added to $10 \%$ final concentration. Rad52-1-226 concentration was determined using an extinction coefficient of $21430 \mathrm{~mole} / \mathrm{l} / \mathrm{cm}$ at $280 \mathrm{~nm}$.

\section{Electron microscopy analysis}

For ring analysis, $\operatorname{Rad} 52$ was diluted to $0.27 \mu \mathrm{M}$ in $10 \mathrm{mM}$ Tris $\mathrm{pH} 7.5,50 \mathrm{mM} \mathrm{KCl}, 2 \mathrm{mM}$ $\mathrm{MgCl}_{2}$, and $1 \mathrm{mM}$ DTT. A fraction of the dilution was deposited onto a 400 mesh copper grid coated with a thin carbon film, previously activated by glow-discharge in the presence of 
pentylamine (Merck, France). After 1 minute, grids were colored with aqueous $2 \%$ (w/v) uranyl acetate (Merck, France) and then dried with ashless filter paper (VWR, France). Observations were carried out using a Thermo fisher TECNAI 12 transmission electron microscope in filtered annular dark field mode. Images were acquired with a Veletta digital camera and the iTEM software (Olympus, Soft Imaging Solutions).

For Rad51 filament transmission electron microscopy studies, a fraction of the following Rad51 filament formation reactions were used. Standard reactions were done by incubating $2.5 \mu \mathrm{M}$ (nucleotides) viral (+) strand of $\phi X 174$ DNA with $1.2 \mu \mathrm{M}$ Rad51 (1:2nt) in a buffer containing $10 \mathrm{mM}$ Tris- $\mathrm{HCl} \mathrm{pH} 7.5,20 \mathrm{mM} \mathrm{NaCl}, 3 \mathrm{mM} \mathrm{MgCl}, 1 \mathrm{mM}$ DTT, and $1.5 \mathrm{mM}$ ATP at $37^{\circ} \mathrm{C}$ for 20 minutes. Then, $0.17 \mu \mathrm{M}$ RPA (1:15nt) was added for 10 minutes. For filament formation in the presence of $\operatorname{Rad} 52,2.5 \mu \mathrm{M} \phi \mathrm{X} 174$ ssDNA was incubated with $0.17 \mu \mathrm{M} \operatorname{RPA}(1: 15 \mathrm{nt})$ at $37{ }^{\circ} \mathrm{C}$ in the same buffer for 10 minutes before addition of $1.2 \mu \mathrm{M} \operatorname{Rad} 51$ (1:2 nt) and $0.17 \mu \mathrm{M} \operatorname{Rad} 52(1: 15 \mathrm{nt})$ at $37^{\circ} \mathrm{C}$ for 20 minutes. The size of partial $\operatorname{Rad} 51$ filaments ranges from 1500 to $2500 \mathrm{~nm}$, and the size of complete Rad51 filaments is $2800 \mathrm{~nm}$. Srs 2 dismantling effect was tested by adding $50 \mathrm{nM}$ Srs 2 to the $\operatorname{Rad} 51$ filament formation reaction at $37^{\circ} \mathrm{C}$ for 5 minutes. Reactions were diluted 10 times, and $5 \mu 1$ of the dilution was deposited onto a 400 mesh copper grid coated with a thin carbon film, previously activated by glow-discharge in the presence of pentylamine (Merck, France). After 1 minute, grids were colored with aqueous 2\% (w/v) uranyl acetate (Merck, France) and then dried with ashless filter paper (VWR, France). Observations were carried out using a Thermo Fisher TECNAI 12 transmission electron microscope. Images were acquired with a Veletta digital camera and the iTEM software (Olympus, Soft Imaging Solutions). 


\section{Electrophoretic mobility shift assay}

Increasing amounts of WT and mutant Rad52-FLAG were incubated with $0.27 \mu \mathrm{M} 5$ ' end-Cy5labeled XV2 oligonucleotide (5'-TGG GTG AAC CTG CAG GTG GGC AAA GAT GTC CTA GCA ATG TAA TCG TCA AGC TTT ATG CCG TT-3') in buffer E (10 mM Tris-HCl pH 8, $5 \mathrm{mM} \mathrm{MgCl}, 100 \mathrm{mM} \mathrm{NaCl}$ ) at $37^{\circ} \mathrm{C}$ for 10 minutes. Complexes were separated on $8 \%$ native polyacrylamide gels. This experiment was also repeated with dsDNA obtained from annealing 5' end-Cy5-labeled XV2 with the complementary sequence.

\section{DNA annealing}

Reactions were performed with 200 nM Cy5-labeled Oligo 25 and 200 nM Oligo 26, two 48nucleotide-long complementary primers described in [47]. Each oligonucleotide was incubated without proteins or with $30 \mathrm{nM} \mathrm{RPA}$ at $30^{\circ} \mathrm{C}$ for 5 minutes, before addition of $40 \mathrm{nM}$ of WT or mutated Rad52. An aliquot of the reaction was collected every 2 minutes and transferred to stop buffer (20 $\mu \mathrm{M}$ unlabeled Oligo $25,0.5 \% \mathrm{SDS}, 0.5 \mathrm{mg} / \mathrm{ml}$ proteinase K). Samples were separated on $8 \%$ native TBE polyacrylamide gels. Fluorescent signals were revealed with a Typhoon 9400 scanner and quantified with the ImageQuant TL software.

\section{DNA strand exchange reaction}

$30 \mu \mathrm{M}$ (nucleotides) viral (+) strand of $\phi X 174$ DNA were coated first with $3.3 \mu \mathrm{M}$ RPA by incubation in SEB buffer (42 mM MOPS pH 7.2, $3 \mathrm{mM} \mathrm{Mg}$ acetate, $1 \mathrm{mM}$ DTT, $20 \mathrm{mM} \mathrm{KCl}$, $25 \mu \mathrm{g} / \mathrm{ml} \mathrm{BSA}$ and $2.5 \mathrm{mM}$ ATP) in a final volume of $12.5 \mu 1$ at $37^{\circ} \mathrm{C}$ for 10 minutes. $\operatorname{Rad} 51$ filament formation was initiated by adding $10 \mu \mathrm{M} \operatorname{Rad} 51$ and $15 \mu \mathrm{M}$ WT or mutated $\operatorname{Rad} 52$, or storage buffer as control, at $37^{\circ} \mathrm{C}$ for 20 minutes. Then, addition of $30 \mu \mathrm{M}$ (nucleotides) of PstIlinearized $\phi \mathrm{X} 174 \mathrm{dsDNA}$ and $4 \mathrm{mM}$ spermidine initiated the strand exchange reaction. After incubation at $37^{\circ} \mathrm{C}$ for 90 minutes, samples were deproteinized by addition of $2 \mu \mathrm{lof} 10 \mathrm{mg} / \mathrm{ml}$ 
proteinase $\mathrm{K}, 5 \% \mathrm{SDS}$ solution at $37^{\circ} \mathrm{C}$ for 10 minutes and analyzed by electrophoresis $(0.8 \%$ agarose gels in $1 \mathrm{x}$ TAE buffer). Standard reactions were done by adding Rad51 prior to RPA. Gels were stained with ethidium bromide and fluorescent signals were imaged with a Typhoon 9400 scanner and quantified with the ImageQuant TL software. The ratio of nicked circular product was calculated as the ratio between the sum of the linear dsDNA substrate and the nicked circular product.

\section{Challenging Rad51 filaments with excess amounts of DNA}

Rad52-catalyzed Rad51 filament formation was performed as follow. $165 \mathrm{nM}$ RPA (1:15 nt) was incubated with $2.5 \mu \mathrm{M}$ of 400 nt-long or 1500 nt-long ssDNA (5' end-Cy5-labeled) in SEB buffer (final volume of $10 \mu \mathrm{l}$ ) at $37^{\circ} \mathrm{C}$ for 10 minutes. After addition of $1.2 \mu \mathrm{M} \operatorname{Rad} 51(1: 2 \mathrm{nt})$ and $165 \mathrm{nM} \operatorname{Rad} 52$ or $\operatorname{Rad} 52-Y 376 \mathrm{~A}(1: 15 \mathrm{nt})$, reactions were incubated at $37^{\circ} \mathrm{C}$ for 30 minutes. Then, $\Phi$ X174 viral (+) strand (from 5 to $12.5 \mu \mathrm{M}$ ) was added and incubated at $37^{\circ} \mathrm{C}$ for 30 minutes. Finally, after fixation with $0.25 \%$ glutaraldehyde, $4 \mu l$ of $40 \%$ sucrose was added to facilitate loading on $0.5 \%$ agarose gel. After electrophoresis in $1 \mathrm{X}$ TAE buffer at $100 \mathrm{~V}$ for 1.5 hours, the fluorescent signals were imagined with a Typhoon 9400 scanner. 


\section{Acknowledgements}

This work benefited from the CryoEM platform of I2BC, supported by the French Infrastructure for Integrated Structural Biology (FRISBI) [ANR-10-INSB-05-05] and member of IBISA. We are especially grateful to Malika Ould Ali for her help with TEM. We also thank Pauline Dupaigne and Eric Le Cam (UMR 9019, IGR, Villejuif) for their help with TEM. We thank the members of the Molecular biology platform (Cigex) of our Institute, Xavier Veaute and Didier Busso for cloning, directed mutagenesis and for RPA, Rad51 and Srs2 purification. We are grateful to Vincent Géli for the gift of RPA antibodies. We also thank Pablo Radicella for critical and careful reading of the manuscript. We also appreciate the help of Elisabetta Andermarcher with the English editing. E.C.'s laboratory was supported by EDF, CEA Radiobiology call and Tandem Call CEA - PIC3i Curie in Radiobiologie.

\section{Author Contributions}

Conceptualization, E.C.; Methodology, E.C., R.G.; Software, R.G.; Validation, E.C., R.G.;

Formal Analysis, E.M., L.M., R.G., E.C.; Investigation, E.M., L.M., L.L.F., R.G., E.C.;

Resources, E.C.; Data Curation, E.M., E.C.; Writing - Original Draft Preparation, E.C.;

Writing - Review \& Editing, L.M., R.G., E.C.; Visualization, E.C.; Supervision, E.C.; Project Administration, E.C.; Funding Acquisition, E.C.

\section{Competing interests}

The authors declare that no competing interests exist. 


\section{Figures and legends}

Figure 1. Mutations in the conserved N-terminal domain of Rad52 suppress MMS and $\gamma$-ray sensitivity in Srs2-deficient cells. (A) Serial 10-fold dilutions of haploid strains with the indicated genotypes were spotted onto rich medium (YPD) containing different MMS concentrations. (B) Survival curves of haploid cells with the indicated genotypes exposed to $\gamma$ ray. (C) Recombination system that allows the formation of a WT ARG4 allele by gene conversion of the $\arg 4-R V$ or $\arg 4-B g$ heteroalleles in diploid cells. (D) Survival curves (left axis) and heteroallelic HR frequencies (right axis) for the indicated homozygous diploid cells exposed to $\gamma$-rays. (E) HO-induced gene conversion between MAT ectopic alleles. (F) Cell survival after HO-induced DSB formation in a SSA repair system. Data are presented as the mean \pm SEM of at least three independent experiments; n.s. $\mathrm{p}>0.05, * * * \mathrm{p}<0.001$ (two-tailed $t$ test). 
rad52-V95I

rad52-V129A

rad52-D79N

srs2 $2 A D 52$

srs2 $\mathrm{rad52-V951}$ srs2 $\mathrm{rad52-V129A}$ srs2 $\triangle$ rad52-D79N

B

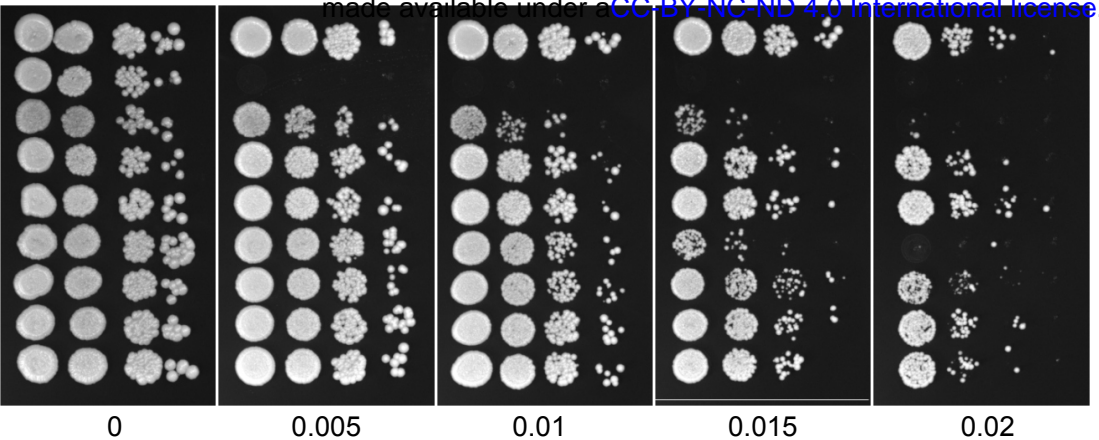

MMS (\%)
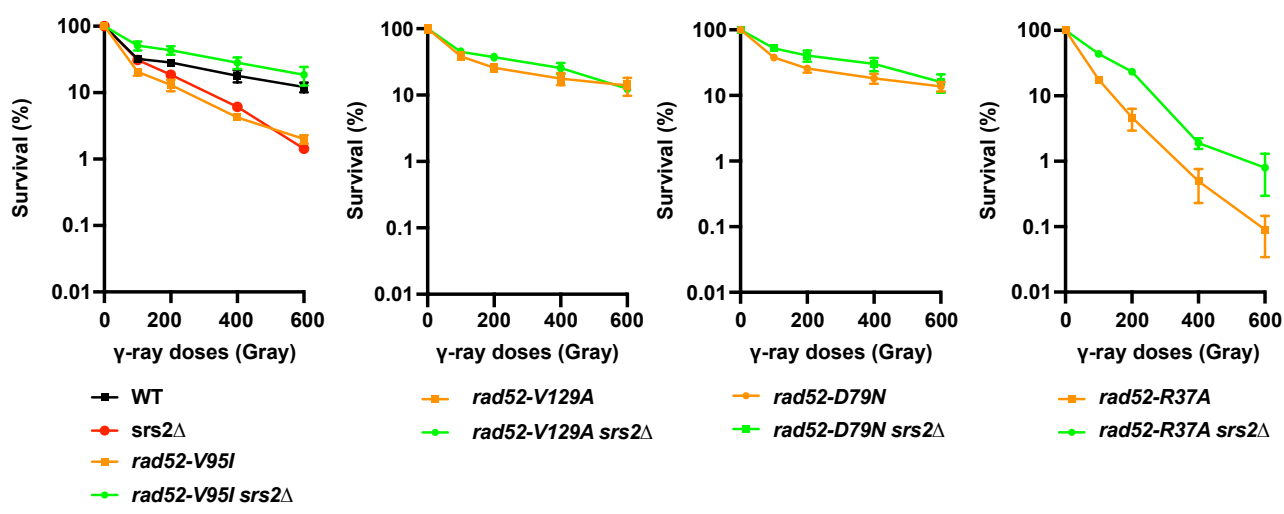

C

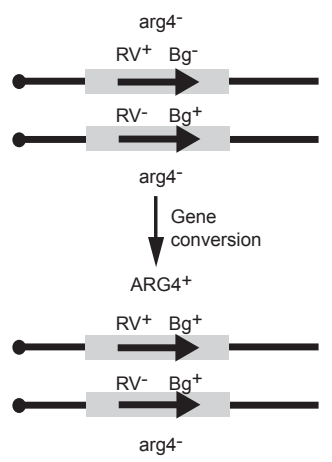

D
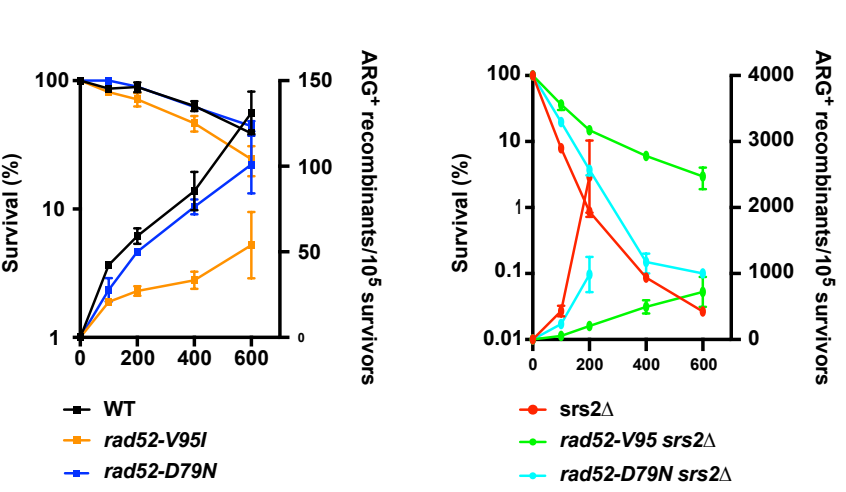

E
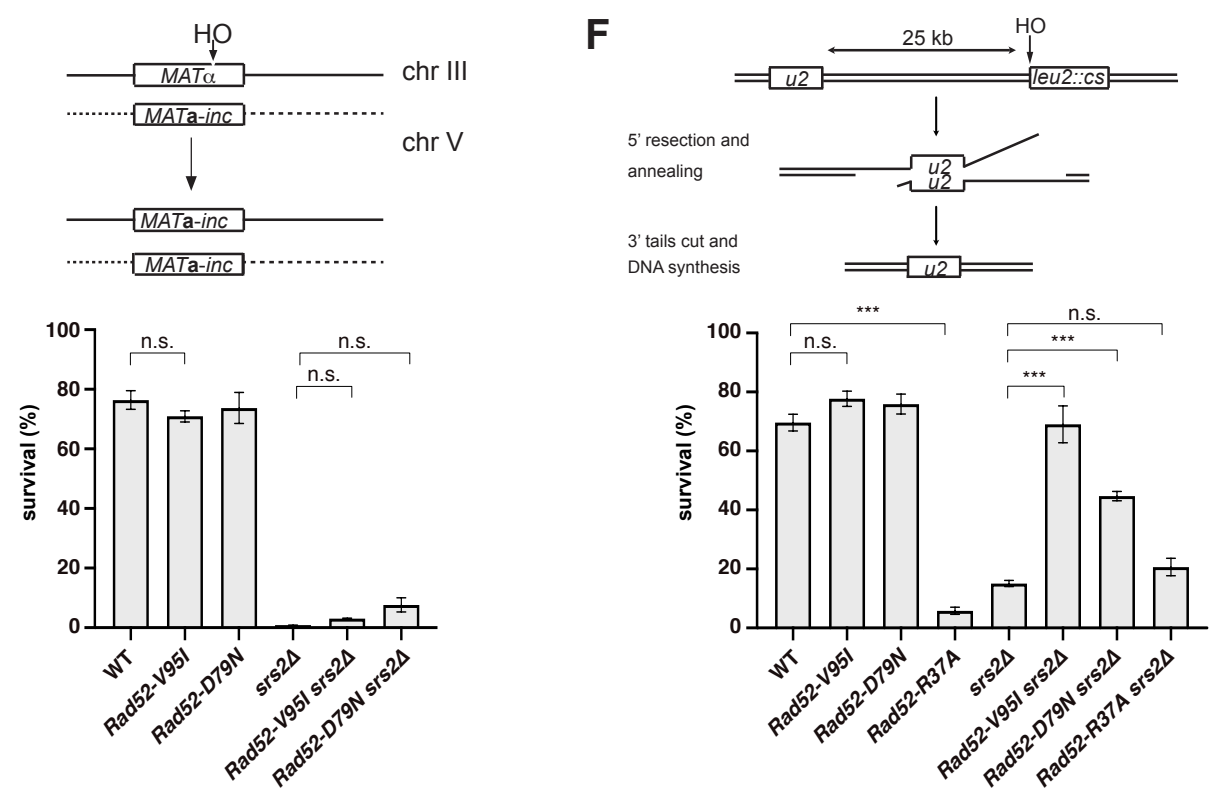

Ma et al. Figure 1 
Figure 2. (A) Structural representation of the model of S. cerevisiae Rad52 assembled as a 11mer using the structure of the human homolog bound to ssDNA as template. One subunit is represented as a rainbow cartoon while the other ten subunits are shown as light grey cartoons and transparent molecular surface. (B) Cartoon representation of a Rad52 monomer colored in the top panel from $\mathrm{N}$ - (blue) to C-terminus (red) and in the lower panel in function of the residue conservation, calculated by the rate4site algorithm with a gradient from white (variable position) to red (conserved position). Residues R37, D79, V95 and V129 are highlighted as pink spheres. (C) Four zoomed views centered on each of the four mutated residues highlighting the mutated residue as a sphere. For V95 (upper left panel), the positions surrounding the V95 sidechain (magenta) are shown as spheres with the color code reporting their conservation, as in B (lower panel). For D79 (upper right panel), located at the interface of two subunits, K117 forms a salt-bridge with D79. V129 (lower left panel) also is at the interface between subunits and is highlighted packing against I106 of a neighboring subunit. R37 (lower right panel) contacts the ssDNA phosphate atoms. 

$\mathrm{N}$-ter (which was pht certified by Peer review) is the author/funder, Who has granted bioRxiv a license to display the preprint in perpetuity. It is
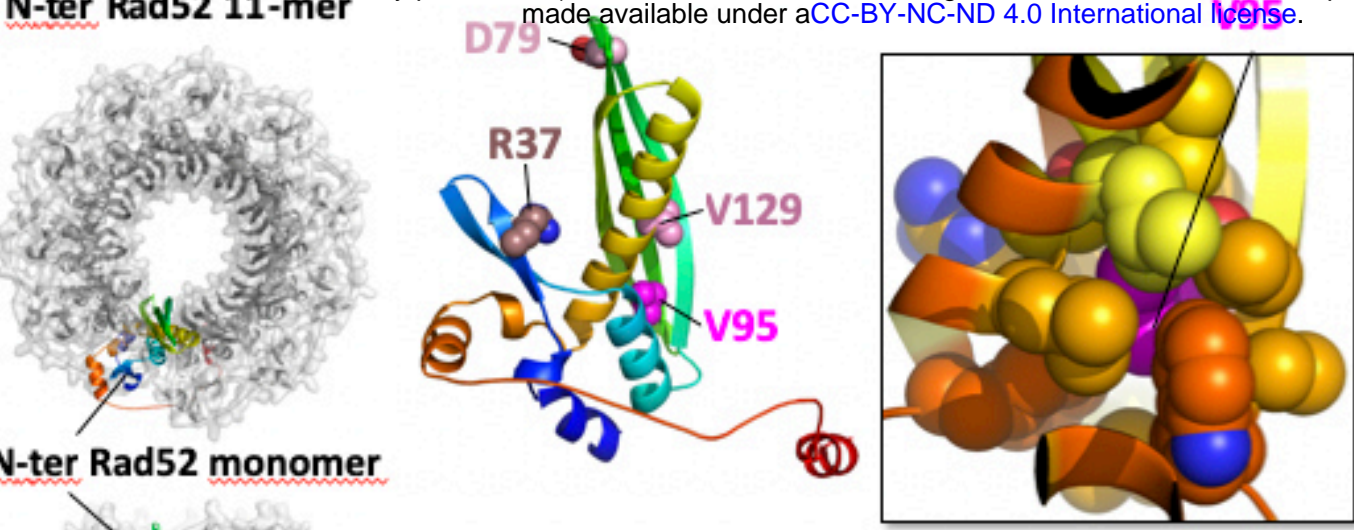
K117 D79

\section{N-ter Rad52 monomer}
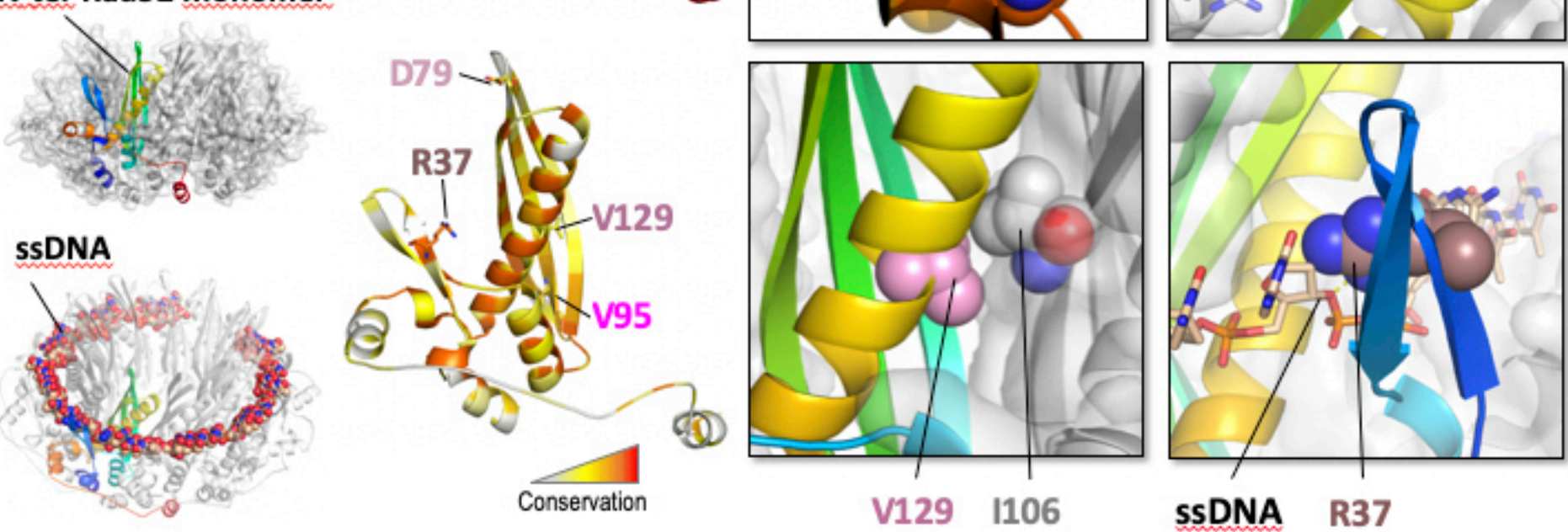

Ma et al. Figure 2 
bioRxiv preprint doi: https://doi.org/10.1101/2021.05.18.444666; this version posted May 21,2021 . The copyright holder for this preprint

(which was not certified by peer review) is the author/funder, who has granted bioRxiv a license to display the preprint in perpetuity. It is made available under aCC-BY-NC-ND 4.0 International license.

Figure 3. Effect of different V95 mutations on MMS sensitivity and Srs2-deficient cell suppression. Serial 10-fold dilutions of haploid strains with the indicated genotypes were spotted onto rich medium (YPD) containing different MMS concentrations. 
bioRxiv preprint doi: https://doi.org/10.1101/2021.05.18.444666; this version posted May 21, 2021. The copyright holder for this preprint

(which was not certified by peer review) is the author/funder, who has granted bioRxiv a license to display the preprint in perpetuity. It is

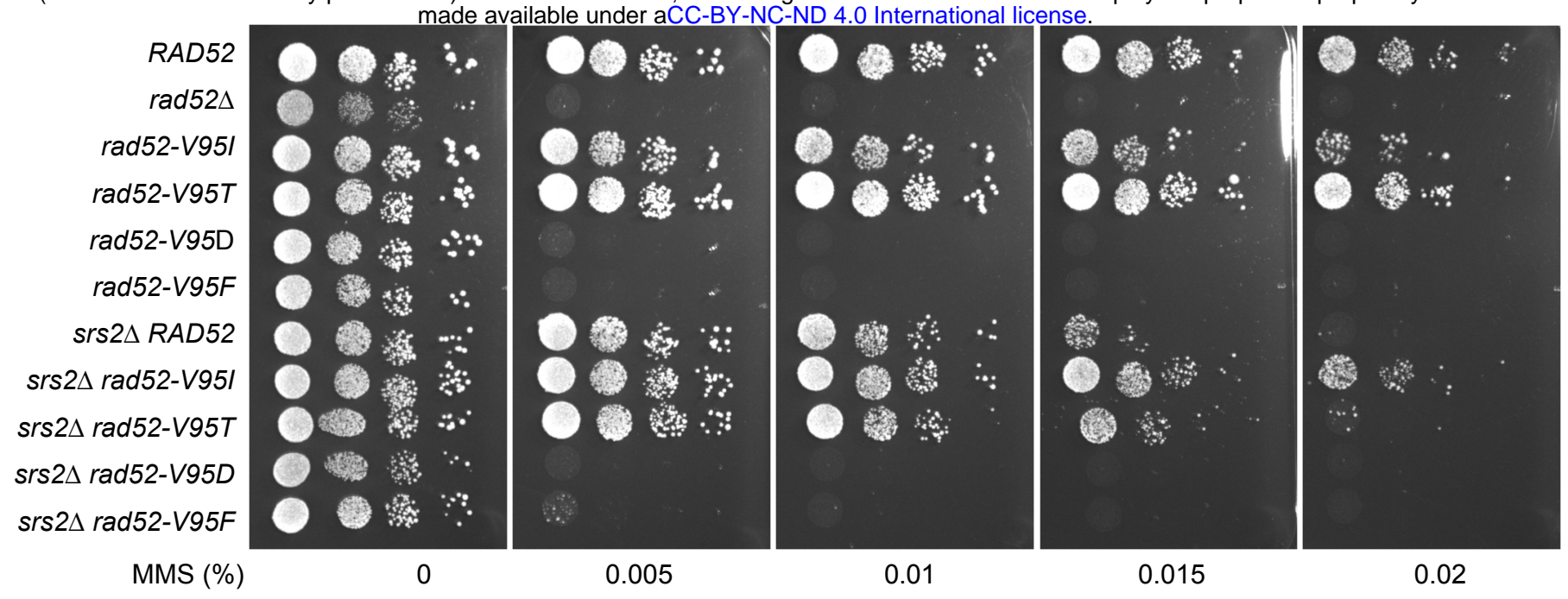

Ma et al. Figure 3 
bioRxiv preprint doi: https://doi.org/10.1101/2021.05.18.444666; this version posted May 21,2021 . The copyright holder for this preprint

(which was not certified by peer review) is the author/funder, who has granted bioRxiv a license to display the preprint in perpetuity. It is made available under aCC-BY-NC-ND 4.0 International license.

Figure 4. Protein decay of wild-type Rad52 and N-terminal Rad52 mutants. (A) Cycloheximide expression shut-off experiments were performed to measure the stability of Rad52-FLAG, Rad52-V95I-FLAG, Rad52V129A-FLAG, Rad52-R37A-FLAG and Rad52-D79N-FLAG. For each time-point, the proteins from whole cell extracts were separated by SDS-PAGE and immunoblotted with mouse anti-FLAG monoclonal antibody. The average of quantification of at least 3 experiments is shown. (B) In vitro stability of Rad52-FLAG and Rad52-V95I-FLAG. 
bioRxiv preprint doi: https://doi.org/10.1101/2021.05.18.444666; this version posted Mav 21, 2021. The copyright holder for this preprint (which was not certified by peer review) is the author/funder, who has granted bioRxiv a license to display the preprint in perpetuity. It is A made available under aCC-BY-NC-ND 4.0 International license.

aFLAG
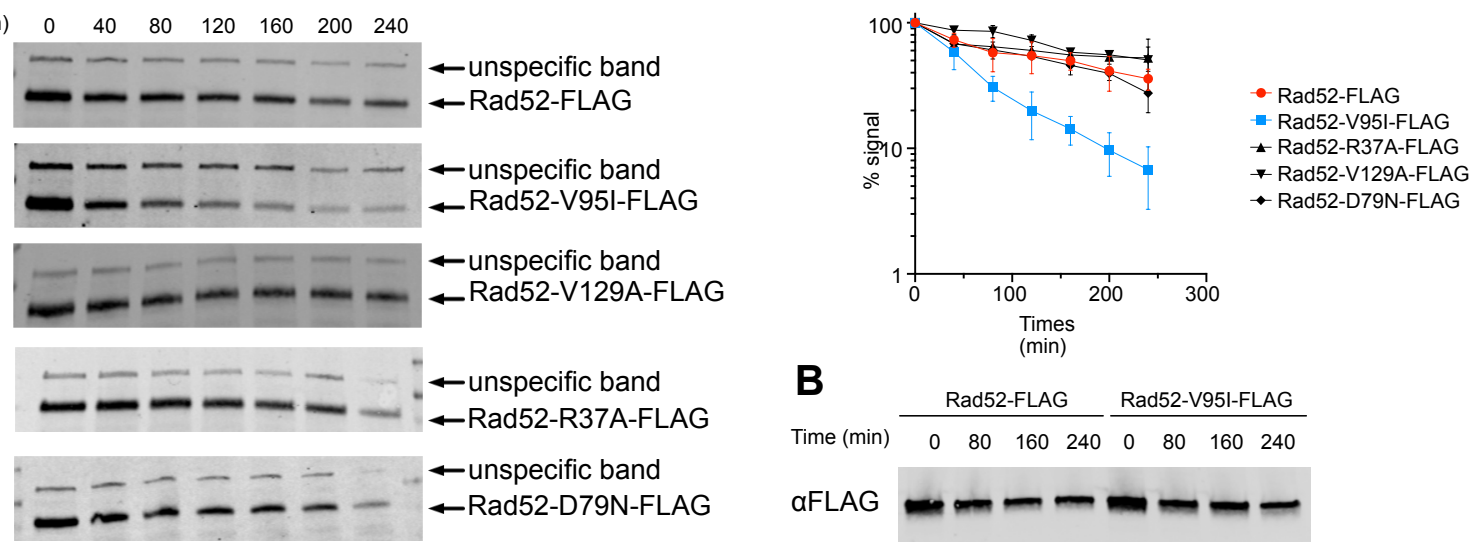

\section{B} Rad52-FLAG Rad52-V951-FLAG

Time (min) $\begin{array}{llllllll}0 & 80 & 160 & 240 & 0 & 80 & 160 & 240\end{array}$

aFLAG

Ma et al. Figure 4 
bioRxiv preprint doi: https://doi.org/10.1101/2021.05.18.444666; this version posted May $21,2021$. The copyright holder for this preprint

(which was not certified by peer review) is the author/funder, who has granted bioRxiv a license to display the preprint in perpetuity. It is made available under aCC-BY-NC-ND 4.0 International license.

Figure 5. EM analysis of Rad52 and Rad52-V95I without DNA (upper panels) or with 400ntssDNA (lower panels). All experiments were performed with FLAG-tagged Rad52 proteins. The protein-ssDNA complex was formed at a ratio of 1:20 nucleotides. Some representative rings with hole (red arrows) and without hole (white arrows) are shown. The percentage of each molecular species is plotted on the histogram (right panel). Two independent experiments were performed with very similar results. The results of the individual biological replicates were pooled (933 molecules analyzed); *** p<0.001 (two-tailed Fisher's exact test). 
bioRxiv preprint doi: https://doi.org/10.1101/2021.05.18.444666; this version posted May 21, 2021. The copyright holder for this preprint (which was not certified by peer review) is the author/funder, who has granted bioRxiv a license to display the preprint in perpetuity. It is

Rad52
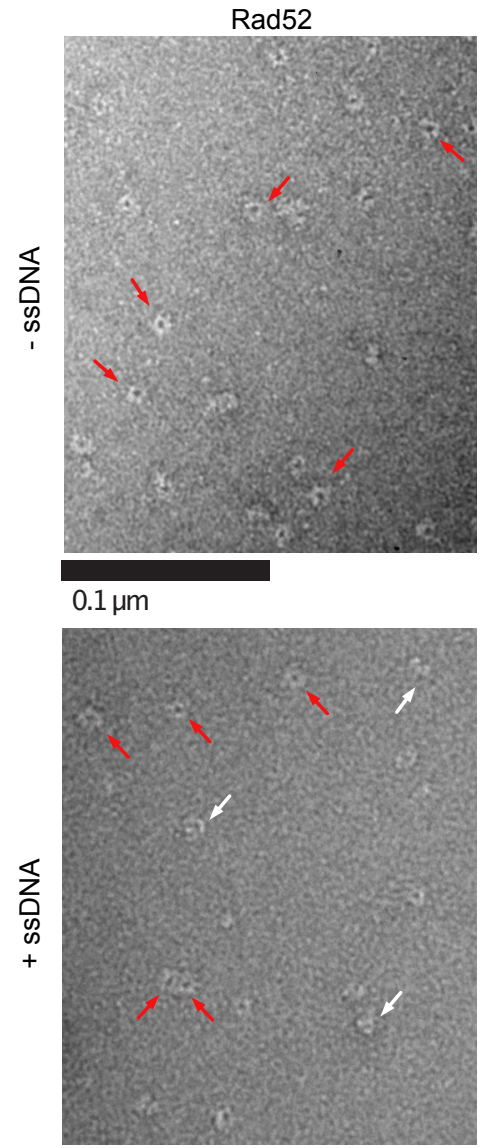

$0.1 \mu \mathrm{m}$

\section{Rad52-V95I}
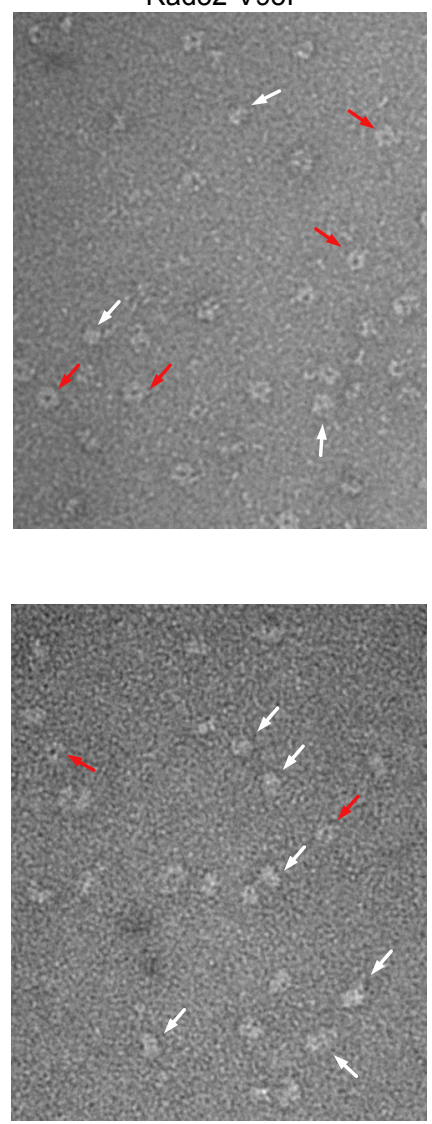

$\square$ ring without hole

ring with hole

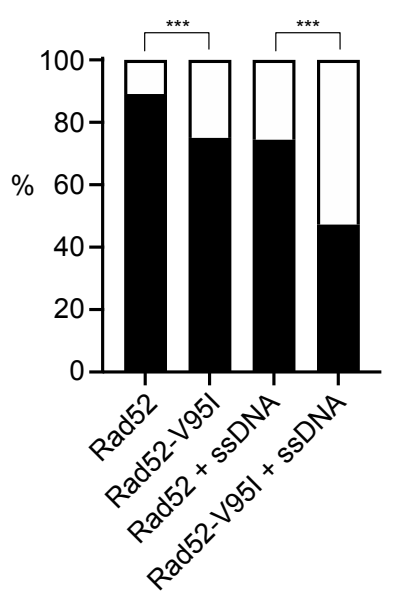

Ma et al. Figure 5 
bioRxiv preprint doi: https://doi.org/10.1101/2021.05.18.444666; this version posted May 21,2021 . The copyright holder for this preprint

(which was not certified by peer review) is the author/funder, who has granted bioRxiv a license to display the preprint in perpetuity. It is made available under aCC-BY-NC-ND 4.0 International license.

Figure 6. DNA binding and strand annealing activity of Rad52-V95I. (A) Binding of purified Rad52-FLAG and Rad52-V95I-FLAG to ssDNA (0.27 $\mu \mathrm{M}$ nt) or dsDNA (0.27 $\mu \mathrm{M} \mathrm{nt})$. (B) Same experiment with a peptide covering the N-terminal domain of Rad52 or Rad52-V95I. The quantification of free ssDNA and dsDNA relative to the peptide concentration is shown. (C) Rad52-FLAG or Rad52-V95I-FLAG annealing activity of a Cy5-labeled 48 nucleotide-long ssDNA to its complementary primer previously coated or not with RPA. The ratio between annealed DNA and the sum of ssDNA and dsDNA was plotted. Data are presented as the mean \pm SEM of at least three independent experiments. 
bioRxiv preprint doi: https://doi.org/10.1101/2021.05.18.444666; this version posted May 21, 2021. The copyright holder for this preprint (which was not certified by peer revie $\mathbb{B}$ is the author/funder, who has granted bioRxiv a license to display the preprint in perpetuity. It is made available under aCC-BY-NC-ND 4.0 International license.
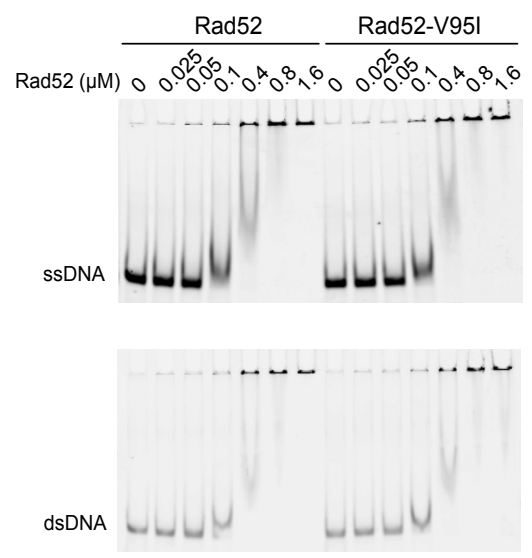
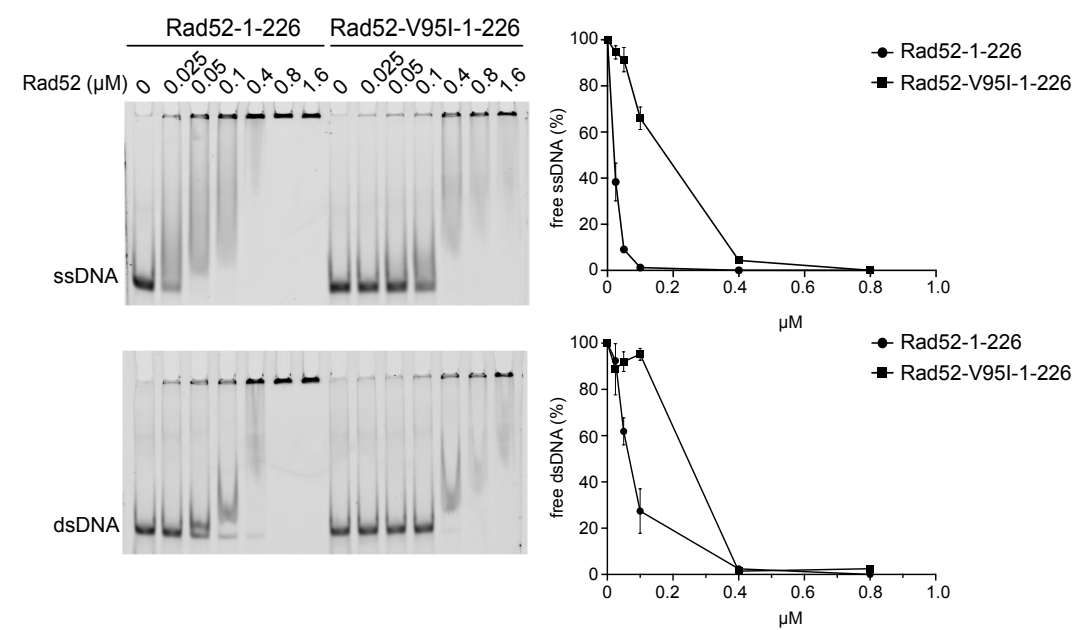

C
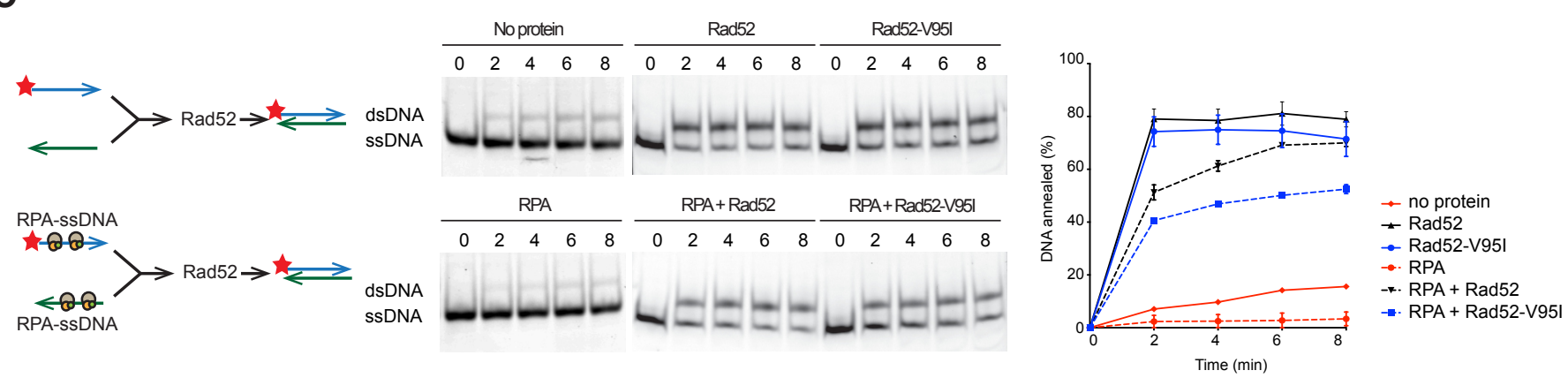

Figure 6. DNA binding and strand annealing activity of Rad52-V95I. (A) Binding of purified Rad52-FLAG and Rad52-V95I-FLAG to ssDNA (0.27 $\mu M$ nt) or dsDNA $(0.27 \mu \mathrm{M} \mathrm{nt})$. (B) Same experiment with a peptide covering the N-terminal domain of Rad52, wild-type or V95I. Quantification of free ssDNA and dsDNA comparatively to the peptide concentration is shown. (C) Rad52-FLAG or Rad52-V95I-FLAG SSDNA annealing activity of a Cy5-labelled 48 nucleotide-long to its complementary primer (upper panel) previously coated or not with RPA. The ratio between annealed DNA and the sum of ssDNA and dsDNA was plotted. Data are presented as the mean \pm SEM of at least three independent experiments.

\section{Ma et al. Figure 6}


Figure 7. Impact of V95I on Rad52-FLAG interaction with partner proteins. (A) Analysis of Rad52-FLAG-Rad59-MYC interaction by co-immunoprecipitation. Rad52-FLAG was precipitated with an anti-FLAG antibody from whole cell extracts. Proteins bound to the antibody were specifically eluted with a 3XFLAG peptide, to avoid the recovery of the antiFLAG antibody in the immunoprecipitated fraction, because Rad59-MYC migrates at the same level as the anti-FLAG antibody. Rad52-FLAG and Rad59-MYC were detected in whole cell extracts and in the immunoprecipitated fraction (IP) with anti-FLAG and -MYC antibodies, respectively. The histogram shows the ratio between the Rad59 signal relative to the Rad52 signal in the immunoprecipitated fraction (mean \pm SEM of at least 2 independent experiments). (B) Analysis of Rad51-Rad52-FLAG interaction by co-immunoprecipitation. Rad51 was immunoprecipitated with an anti-Rad51 antibody. The presence of Rad51 in the immunoprecipitated fraction (IP) cannot be detected because it migrates at the same level as the anti-Rad51 IgG used for the immunoprecipitation. However, the absence of Rad52 in the rad51 $\Delta$ immunoprecipitate confirmed that the Rad52-FLAG signals observed are related to the Rad52-Rad51 interaction. The signals corresponding to immunoprecipitated Rad52-FLAG relative to Rad52-FLAG in the whole extract were quantified in two independent experiments and are shown as the mean \pm SEM (histogram on the right). (C) Analysis of RPA-Rad52-FLAG interaction by co-immunoprecipitation. Rad52-FLAG was precipitated with an anti-FLAG antibody from whole cell extracts. RPA was detected with a polyclonal anti-RPA antibody. The histograms show the ratio between the Rfa1 subunit of RPA signal relative to the Rad52 signal in the immunoprecipated fraction (mean \pm SEM of at least 2 independent experiments). (D) Analysis of the interaction between Rad52-FLAG and a Srs2 C-terminal peptide by $\mathrm{Y} 2 \mathrm{H}$ analysis. $\beta$-galactosidase activity was measured in CTY10d cells carrying pACT2-GAL4AD (pA)-Srs2Cter and pBTM116-LexABD (pB)-Rad52 or -Rad52-V95I. The median values of $\beta$ - 
bioRxiv preprint doi: https://doi.org/10.1101/2021.05.18.444666; this version posted May $21,2021$. The copyright holder for this preprint (which was not certified by peer review) is the author/funder, who has granted bioRxiv a license to display the preprint in perpetuity. It is made available under aCC-BY-NC-ND 4.0 International license.

galactosidase activity are shown (red line). (A), (B) and (C) n.s. p $>0.05$, *** p<0.001 (twotailed $t$ test), (D) n.s. $\mathrm{p}>0.05, * * * \mathrm{p}<0.001$ (two-tailed Mann and Whitney test). 
A

bioRxiv preprint doi: https://doi.org/10.1101/2021.05.18.444666; this version posted May 21, 2021. The copyright holder for this preprint (which was not certified by peer review) is the author/funder, who has granted bioRxiv a license to display the preprint in perpetuity. It is made available under aCC-BY-NC-ND 4.0 International license.

B
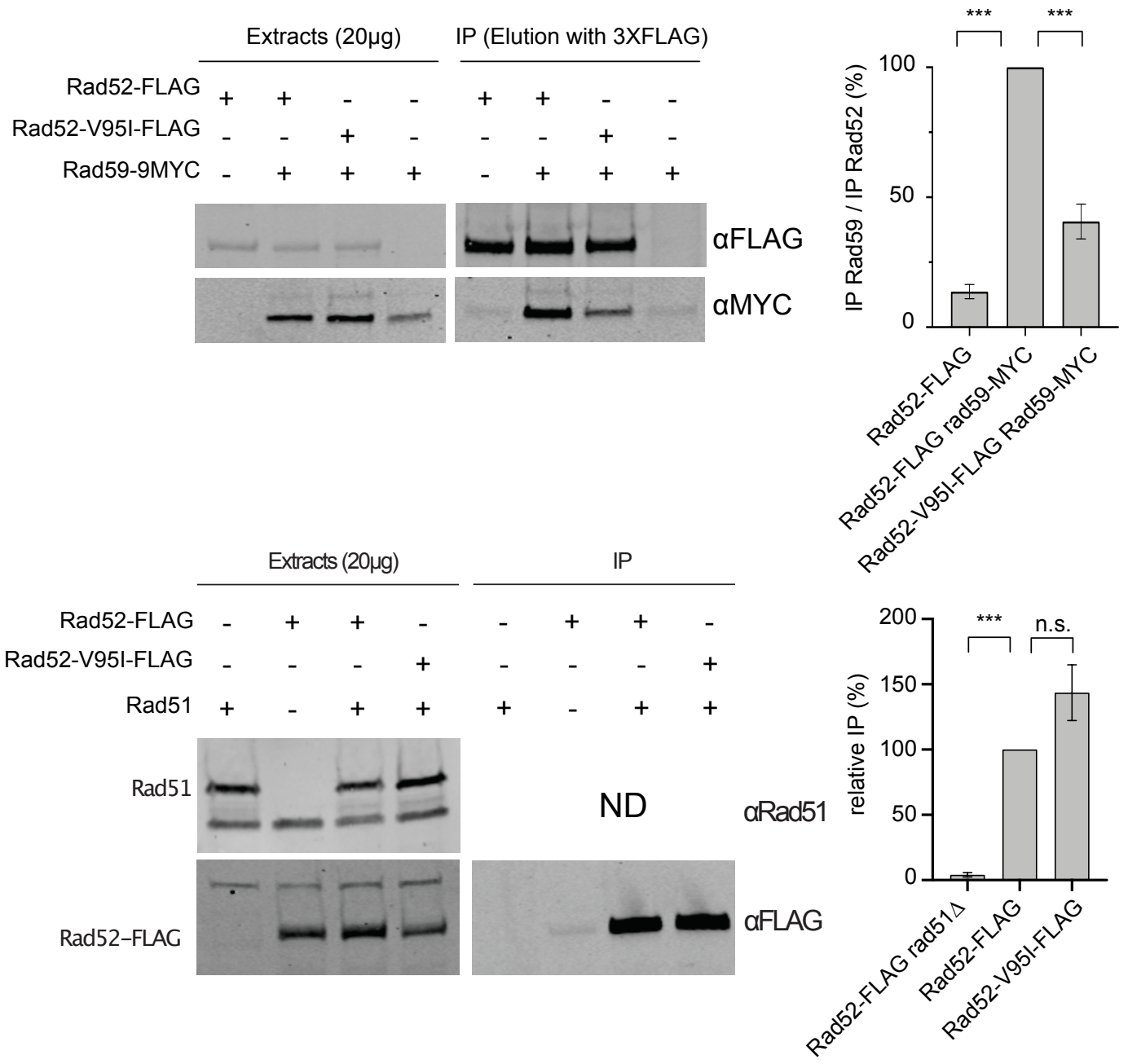

C
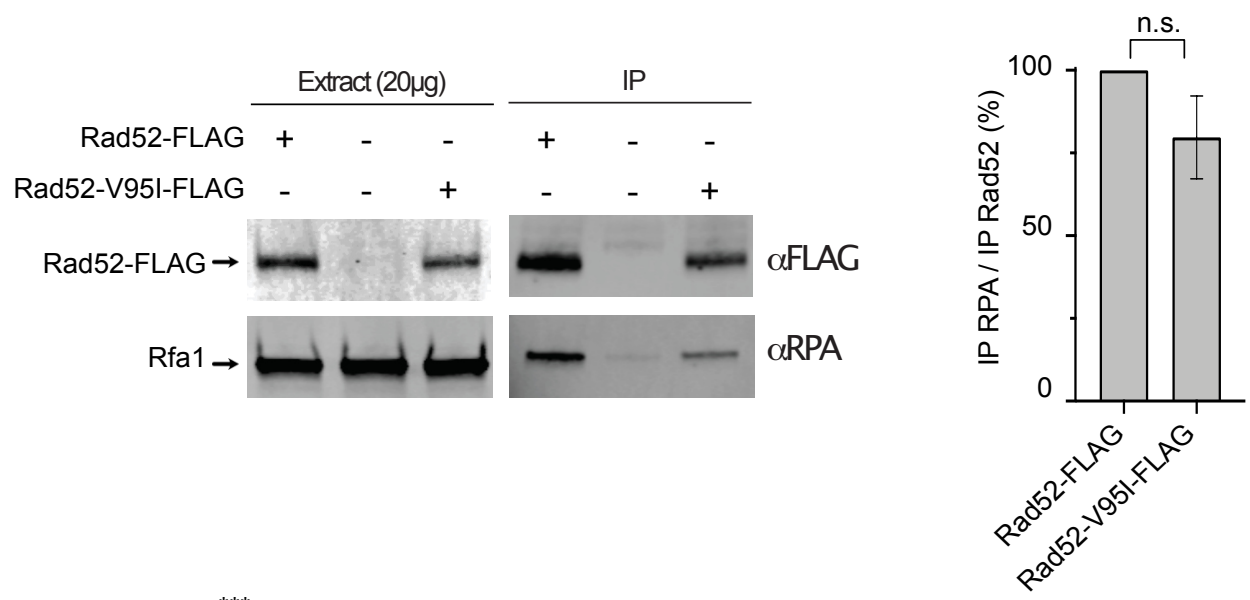

D

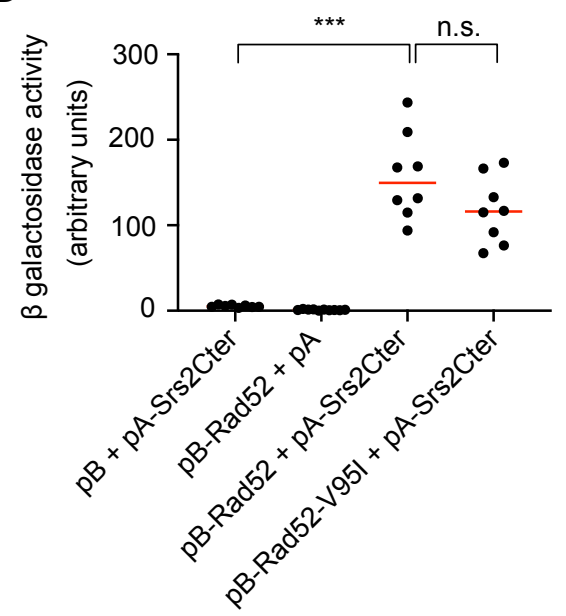


bioRxiv preprint doi: https://doi.org/10.1101/2021.05.18.444666; this version posted May $21,2021$. The copyright holder for this preprint

(which was not certified by peer review) is the author/funder, who has granted bioRxiv a license to display the preprint in perpetuity. It is made available under aCC-BY-NC-ND 4.0 International license.

Figure 8. ChIP analysis of Rad51 filament formation at a DSB created by the HO endonuclease.

(A) Schematic of the HO-induced SSA repair system. The used primers are shown. (B) ChIP was used to assess RPA, Rad52 and Rad51 relative enrichment at $0.6 \mathrm{~kb}$ (red) and $7.6 \mathrm{~kb}$ (green) from the DSB site and at the uncut $A R G 5,6$ locus (blue) at the indicated time points (hours) after $\mathrm{HO}$ induction. The median value $(\mathrm{n}=3$ or 4$)$ is shown and error bars represent the upper and lower values; ${ }^{*} \mathrm{p}<0.05, * * \mathrm{p}<0.01, * * * \mathrm{p}<0.001$ (unpaired $t$ test for the value at $4 \mathrm{hr}$ after HO-induction; only significant differences are shown). 
bioRxiv preprint doi: https://doi.org/10.1101/2021.05.18.444666; this version posted May 21,2021 . The copyright holder for this preprint

(which was not certified by peer review) is the author/funder, who has granted bioRxiv a license to display the preprint in perpetuity. It is

A $25 \mathrm{~kb}$ meade available under aCC-BY-NC-ND 4.0 International license.

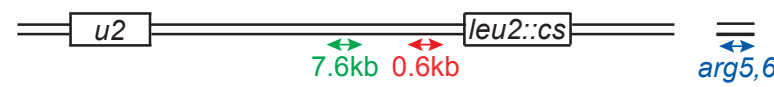

B

WT

$\operatorname{srs} 2 \Delta$

Rad52-V95I

Rad52-V95I

Rad52-R37A

Rad52-R37A
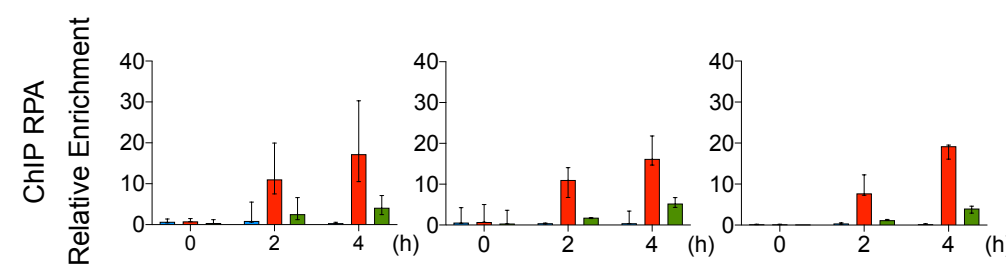

$\operatorname{srs} 2 \Delta$

$\operatorname{srs} 2 \Delta$
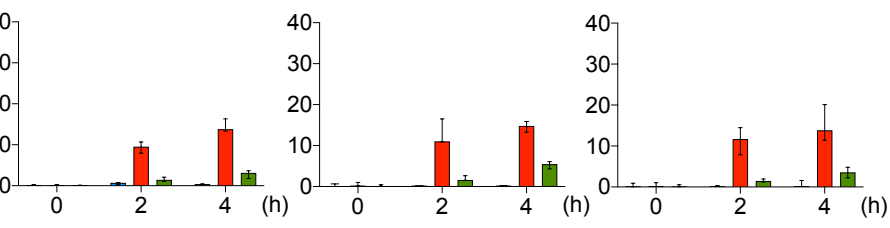

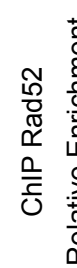
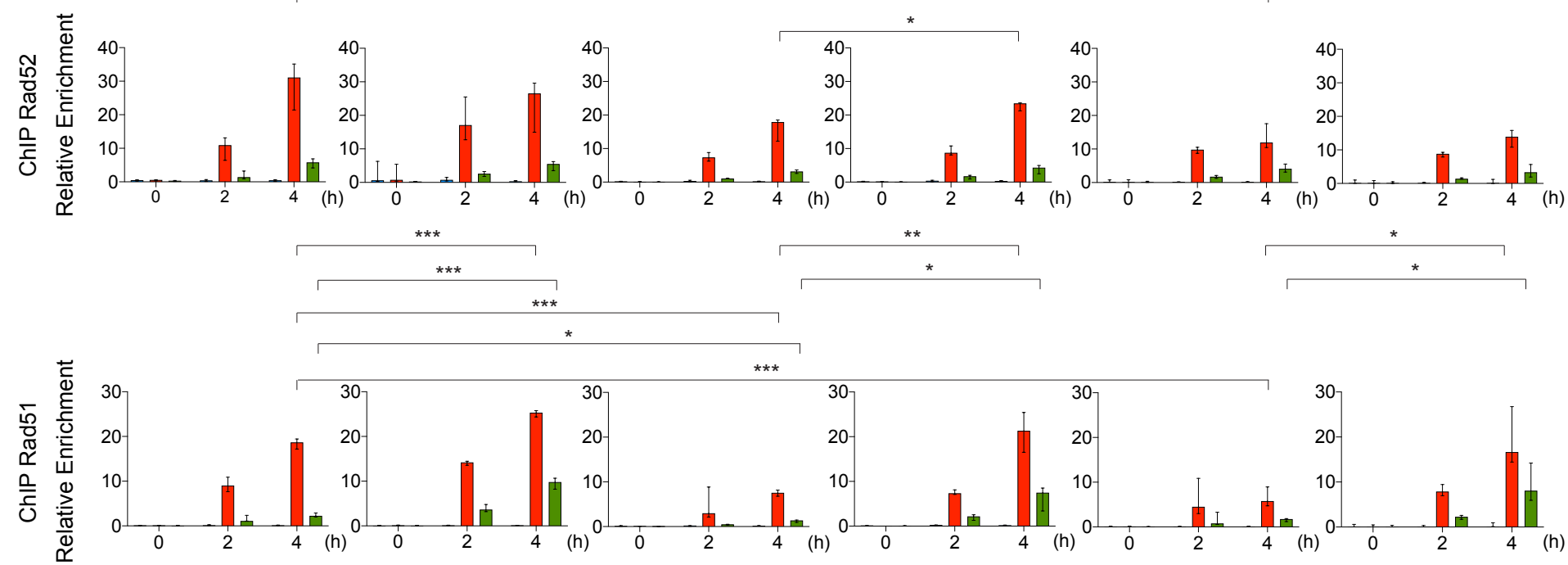

Ma et al. Figure 8 
Figure 9. Rad51 filament formation by Rad52-V95I. All experiments were performed with FLAG-tagged Rad52 proteins. (A) EM analysis of Rad51 filament formation. A representative nucleofilament issued from each reaction is shown. Addition of RPA before Rad51 (RPA+Rad51) results in the formation of partial Rad51 filaments. White arrows indicate the presence of RPA on ssDNA. Concomitant addition of Rad52 with Rad51 in this reaction (RPA+Rad51+Rad52) leads to complete Rad51 filaments associated with Rad52 (red arrows). The percentage of each molecular species is plotted on the histogram (right panel). Two independent experiments were performed with very similar results. The results of the individual biological replicates were pooled (170 molecules analyzed); n.s. p $>0.05$, *** $\mathrm{p}<0.001$ (twotailed Fisher-Freeman-Hamilton exact test). (B) Number of Rad52 and Rad52-V95I molecules associated with Rad51 filaments $(n>35)$. The median value is represented by the horizontal bar; $p>0.05$ (two-tailed Mann \& Whitney test). (C) Effect of Rad52-V95I on strand exchange. The standard reaction (Rad51+RPA) shows that complete Rad51 filaments catalyze the formation of nicked circular products. Pre-bound RPA inhibits this reaction (RPA+Rad51); however, the inhibitory effect of pre-bound RPA is overcome by Rad52 and Rad52-V95I (RPA+Rad51+Rad52). The percentage of nicked circular products calculated by quantification of the gels is shown. Data are presented as the mean \pm SEM of at least three independent experiments; n.s. p $>0.05, * * * \mathrm{p}<0.001$ (unpaired $t$ test). (D) EM analysis of Rad51 filament displacement by Srs2. Srs 2 was added for 5 minutes at the end of the Rad51 filament formation reactions. White arrows show the appearance of RPA on Rad52-V95I-assembled Rad51 filaments after Srs2 addition. The percentage of each molecular species is shown in the histogram (right panel). Two independent experiments were performed with very similar results. The results of the individual biological replicates were pooled (160 molecules analyzed); $* * * \mathrm{p}<0.001$ (two-tailed Fisher-Freeman-Hamilton exact test). 
bioRxiv preprint doi: https://doi.org/10.1101/2021.05.18.444666; this version posted May 21, 2021. The copyright holder for this preprint (which was not certified by peer review) is the author/funder, who has granted bioRxiv a license to display the preprint in perpetuity. It is made available under aCC-BY-NC-ND 4.0 International license.

A

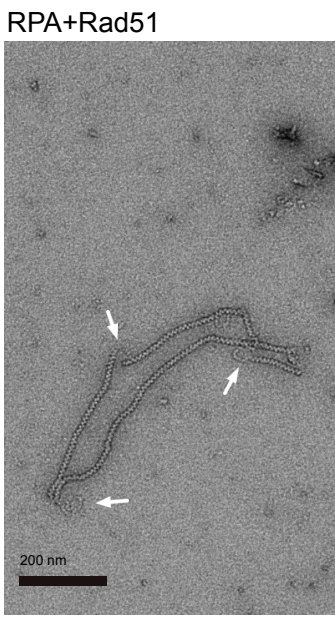

RPA+Rad51+Rad52

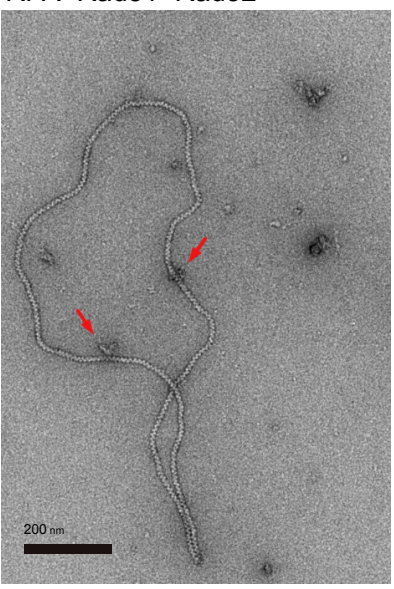

RPA+Rad51+Rad52-V95I

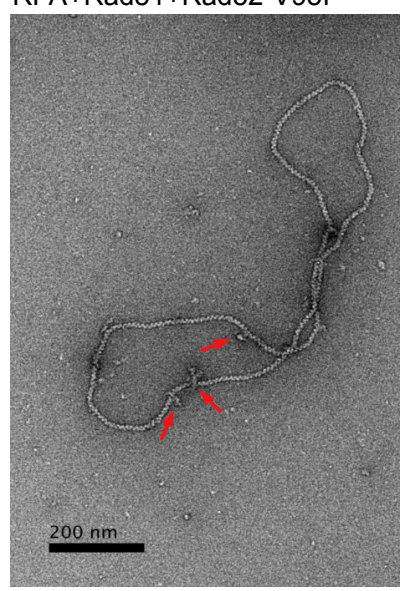

$\square$ RPA filaments

$\square$ partial Rad51 filaments

complet Rad51 filaments

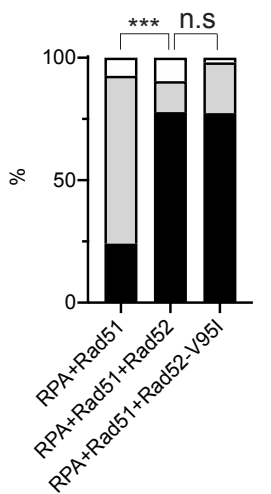

B

C

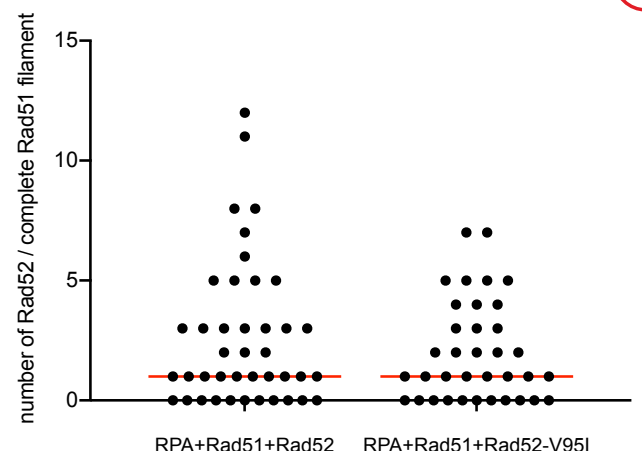

$\bigcirc+\operatorname{RPA} \stackrel{10 \mathrm{~min}}{\longrightarrow}+\operatorname{Rad} 51+\operatorname{Rad} 52 \stackrel{20 \mathrm{~min}}{\longrightarrow}+$
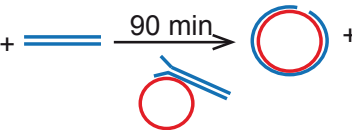

D
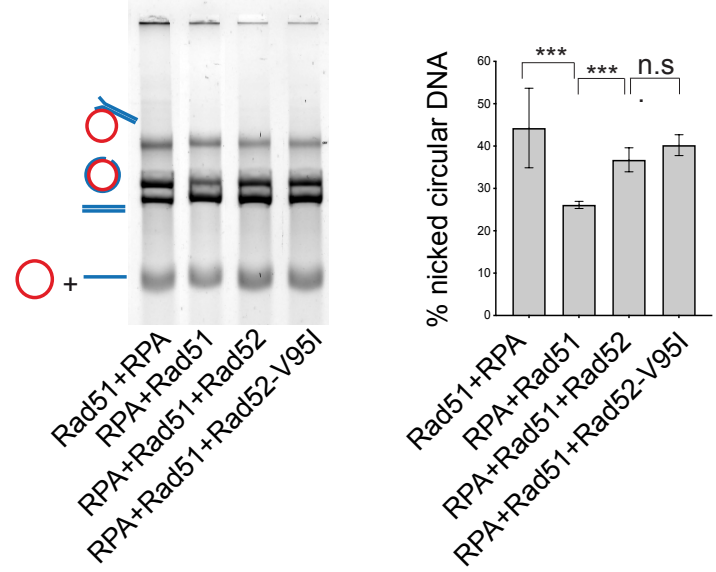

RPA+Rad51+Rad52 RPA+Rad51+Rad52-V951
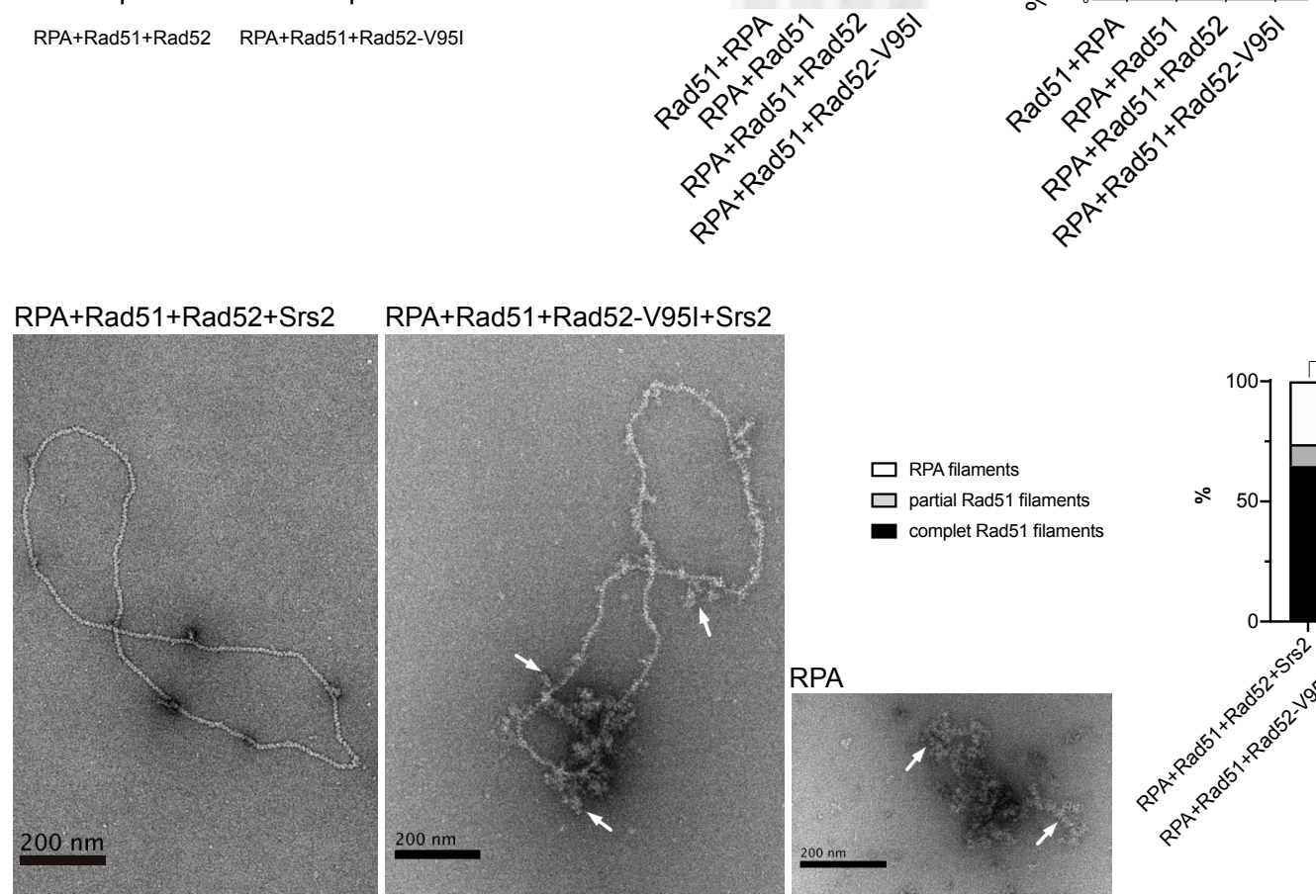

RPA+Rad51+Rad52-V95I+Srs2
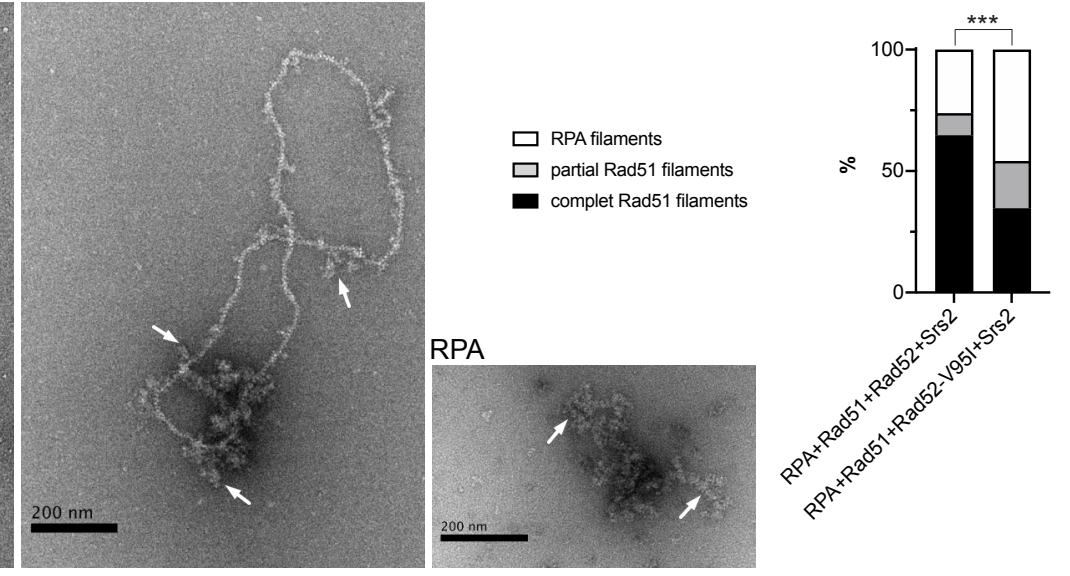

Ma et al. Figure 9 
Figure S1. Multiple sequence alignment of a set of 22 representative homologs of S. cerevisiae Rad52 (shown on top) restricted to the N-terminal domain region (residues 1-178). The accession number of each homolog is indicated in brackets in the sequence description. The amino acid colors refer to the chemical character of the residues. On top of the alignment the positions of the mutated residues are indicated by a colored circle. 
bioRxiv preprint doi: https://doi.org/10.1101/2021.05.18.444666; this version posted May 21, 2021. The copyright holder for this preprint (which was not certified by peer review) is the author/funder, who has granted bioRxiv a license to display the preprint in perpetuity. It is made available under aCC-BY-NC-ND 4.0 International license.

Saccharomyces cerevisiae (NP 013680) 1-178
Candida intermedia (SGZ52089) 70-241
Scheffersomyces stipitis (KAG2731386) 39-210
Venturia nashicola (TID15606) 268-441
Gaeumannomyces tritici (XP 009216721) 19-193
Microthyrium microscopicum (KAF2663961) 19-192
Trichodelitschia bisporula (KAF2399158) 22-195
Lodderomyces elongisporus (XP 001523822) 47-218
Candida maltosa (EMG45758) 42-214
Thermothelomyces thermophilus (XP 003662232) 19-193
Hysterangium stoloniferum (KAF8518349) 49-223
Phaeomoniella chlamydospora (KKY17786) 347-521
Chaetothyriales sp. (RMZ75599) 767-941
Thelephora terrestris (KAF9788305) 64-238
Panaeolus cyanescens (PPQ99253) 61-233
Mycena kentingensis (KAF7307718) 64-239
Aspergillus ellipticus (PYH95147) 53-227
Tremella mesenterica (RXK39941) 40-214
Candida viswanathii (RCK58135) 51-223
Saitozyma podzolica (RSH91138) 104-275
Bondarzewia mesenterica (THH14411) 29-203
Linnemannia elongata (KAF9287890) 38-213

Saccharomyces cerevisiae (NP 013680) 1-178 Candida intermedia (SGZ52089) 70-241 Scheffersomyces stipitis (KAG2731386) 39-210 Venturia nashicola (TID15606) 268-441 Gaeumannomyces tritici (XP 009216721) 19-193 Microthynium microscopicum (KAF2663961) 19-192 Trichodelitschia bisporula (KAF2399158) 22-195 Lodderomyces elongisporus (XP 001523822) 47-218 Candida maltosa (EMG45758) 42-214 Thermothelomyces thermophilus (XP 003662232) 19-193 Hysterangium stoloniferum (KAF8518349) 49-223 Phaeomoniella chlamydospora (KKY17786) 347-521 Chaetothyriales sp. (RMZ75599) 767-941 Thelephora terrestris (KAF9788305) 64-238 Panaeolus cyanescens (PPQ99253) 61-233 Mycena kentingensis (KAF7307718) 64-239 Aspergillus ellipticus (PYH95147) 53-227 Tremella mesenterica (RXK39941) 40-214 Candida viswanathii (RCK58135) 51-223 Saitozyma podzolica (RSH91138) 104-275 Bondarzewia mesenterica (THH14411) 29-203 Bondarzewia mesenterica (THH14411) 29-203
Linnemannia elongata (KAF9287890) 38-213

Ma et al. Figure S1
R37

D79

V95

O

(1)

0

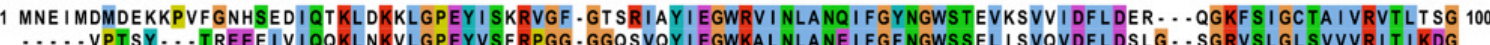
..... QPVPY...AEEEEKRIOSNLNRVLGPEYVSFRPGG.GGTTVSYIEGWKAL NLANE IFGF NGWNSEI VGERVDFLESGG..PGRFSMGFTAQIRVTLKDG ..PP.RISEY...SAQEIAQLOSRLDKQLGPEYISSRQGP.GGGKVHYLAAEKVI NLANEVFGF NGWSSEI KDVTIDYVDVE-K.DGRITMGCSIIVRITLRDG - RP.RLSLW. - . TAQE IAALQTRLDRQLGPEYLSARSGP.SGQKVHYVAADKI I SLANDVFGFNGWST S QDVQVDFADVNPQ-TGKISLGLSVVVRVTLRDG

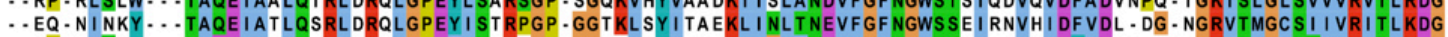
. IP.RMSEY... TAEEIATI AKLDRQLPEFI SSRKGP.GGKSFHYVAAEKVIGIANEVFGFNGWSSAIQNVTIDYVDID.K.SGKVSMGCSTIVRVTLKDG .... QPIDF...TENERITIQTKLNKALGPEYVSSRPGG. HGA. VQYIEGWKALNLANEIFGF NGWNSELVSCEIDFFDTHGN.TGKCSLGLSIVVRITLKDG ......APTPY... TDEEYLE IONKL NRVLGPEYVSYRPSG.GGQKVQYI EGWKALNLANEVFGF NGWNSEI IGCNI DYLDT HGN. SGKFSLGLSMIVRITIRDG

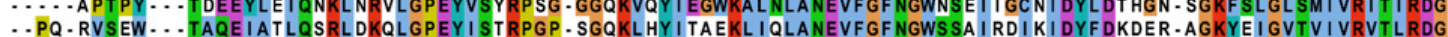
H.... DI SVA.... THKDIASLAKLDOKLGPEYVSORPGPGGGPKLTYAEGWKI INLANEIFGF NGWSSS ICSL TVDYLDPHDE.GRPWNCGVSA IVRVTLRDG

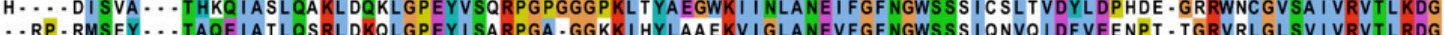
.QQQ.QVGGY... SAVEVATLQGRLDKQLGPEY ISSRLGP.GGGRVHYLAADKVIGLANEIFGF NGWSSAIQQIQIDFVDEHPT. TGKVSLGLSVVVRVTLKDG

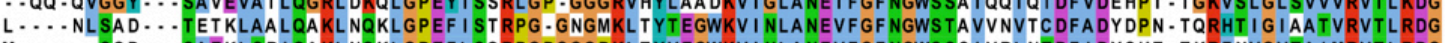
M............ SQDEKLSRIQAKL NQKLGPEFLSQRPGPGG PKLTYVEGWKV I NLANEVFGFNGWSSS I VRLNTDF I DYSHE - TKRFNVGVTA IMRVTLRDG IS.S-ALSES ...VVFDRVNRLQAKLNQKLGPEFVSQRPGHGG PKLTYAEGWKI I NVANEVFGYQGWSSS I VSMT T DYCDLTEQ - KKYNVGVSVVMRVTLQEG -KQ-RLNEY...TAQE I ATLQARLDKKLGPEYI SSRPGA-AGQRVHYLPADKV I NLANEVFGF NGWSSS I QN I TVDYVEENPN-TGKVNCGLSVVVRVTLRDG .GA.KFTQW.... SEEKVATLQARLA KKLGPEYI TQRPGPAGGPKLSYVEGWKV I NLANQVFSF NGWSSS I VSLT TDFLDCNDQG.-RVSVNVTA IVRI TLQDG … DPVPY.-..TPEEFAR I Q SKL NEVLGKEYVSDRPAG.GGQT VKY I EGWKALNLA NE I FGF NGWNTE I I TCNVDYFDPHDG.ATKF SLGL SMVVRVTLRDG

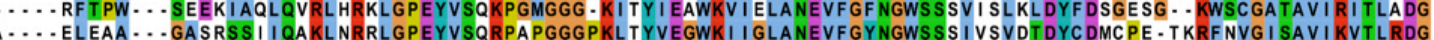

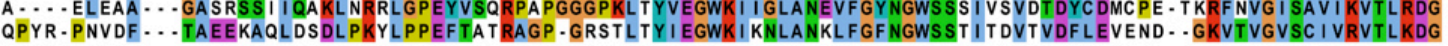

\section{V129}

101 TYREDIGYGTVENERRKPAAFERAKKSAVTDALKRSLRGFGNLGNCLYKDFLAKIDKVKFDP.PDFDENNLFR.PTDE 178 TFHEDFGYGF I ENAKT KAAAFEKCKKEAFTDGLKRCLRCFGNVLGNCLYDKTI IARTQKVKLAP-MELEKDDFYRDPLVI TYHEDYGYGY I ENAKSKAMAFEKCKKEA I TDG I KRCLRCF GNVLGNCLYDRTII KQ I KNVQLPK. GEYEDSDFHRDPGLV THHEDI GYGE I KNANGKGAAFEKA KKEAAT DAVKRALRTF GNVLGNCL YDKSYLQKI TKVKVEP. SRWDVDKL HRHHDYA TFHEDMGYGH I ENC KS KA SAFE KA KKEGT T DAL KRALRHF GNLL GNC I YDKDYLAKVTKI KVAP - TKF DESGL HRHSDFV TFHEDIGYGE I KNSP SKAAAFEKT KKEA ST DAL KRTLRNF GNLL GNCL Y DKTYTDKI SKVKT DP. I QWNADDL HRHHSHP TYHEDI GYGET SNMPGKGQAFEKI KKEASTDALKRALRSF GNVL GNC I YDKDYVSKVSRMKTLP - A KWDEDNLHRHPDF I TYHED I GYGF I ENA RN KA TAFEKC KKEAFT DG I KRCL RCFGNVL GNCL YDKT I VKQMEKVKKPP. VEYQEEDF HRDRLLV TYHED I GYG YVDNC KS KAMAFEKC KKEALT DA VKRCLRCF GNVL GNCL YDKT I VAQMNKMKEAP - I QYQPENF HRDPLLV TYHEDLGFGHTEN I RNKYQAFEKA KKAGT T DALKRTLRQFGSLLGNC I YDKAYLSKVTKLKPVP.VRFDENALHRHPDYV

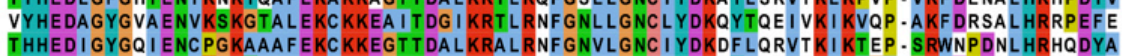
TYHEDVGYGSVENARGKSAAFEKAKKEGTTDALKRALRNF GNLLNCI YDKEYVSRITKVKVGA.GKWDPDTLHRHRDFE VYHEDIGYGMMENSKS KAAAF DKCRKEAVT DALKRALRNF GNLLGNCL Y DKEYTKEI HKI KAPPPPKLDKDSLHRRPDFV I FHEDVGFGFLENSRS KAAA I DKCNKEAVTDGL KRALRNFGN I LGNCLYDKSYTADVMKVKAEP.AKFREEELHRRPEYN AYHEDVGYGSMENSKS KGAAL DKC KKEAVT DALKRALRNFGNVMGNCL YDKQYTQE IVKIKVPP - VKLLRDNLYRI PAFS TYHED I GYGHMDNA KG KA I ALEKA KKEGT T DAL KRALRSF GNVL GNCVYDKEYVSKVT KMKATP. A KWDVEEL HRHQDYA CFHEDVGCGQCENVRGKGAAL DKAKKEAVT DATKRALKTFGNLL GNCL YDKDYTKE I VKMKVPP. AKFNVSDLERRPEFT TFHEDIGYGYVDNCKS KAMAF EKC KKEALT DGVKRCLRCF GNLLGNCL YDKSYLAQLAKI KKTV - I QYQPEDYHHDPLLV TFHEDVGCGSMENSRS KAQMWDKAQKEAVTDG I KRCLKTF GNVL GNCLY YKDYNRE I GKVKVPP. FKLNHDQLERRPEFA TSHEDVGYGTA DNL KSKGAAL DKA KKEAVT DGMKRALRNFGNLLGLCLYES FAQEVVKI KAPP. P IF DKSDL HRRPDYE TFHEDMGYGSSENQKSKGA SFEKA KKEAVT DALKRALTSF GNLLGTCLYDKNYAKYLSTQRFDK - AKYNEVEFYTYPTEA 
Figure S2. The rad52-V95I mutation suppresses the effect of mutations that are synthetically lethal with $\operatorname{srs} 2 \Delta$. Tetrad analysis of crosses between haploid rad52-V95I srs $2 \Delta$ strains and haploid mutants that are synthetically lethal with $\operatorname{srs} 2 \Delta$. Double mutant spores, which do not contain rad52-V95I, are indicated by white squares. The white circles mark viable triple mutants. 
bioRxiv preprint doi: https://doi.org/10.1101/2021.05.18.444666; this version posted May 21, 2021. The copyright holder for this preprint

(which was not certified by peer review) is the author/funder, who has granted bioRxiv a license to display the preprint in perpetuity. It is rad52-V95I srs $24 \mathrm{x}$ made available under aCC-BY-NC-ND 4.0 International license.

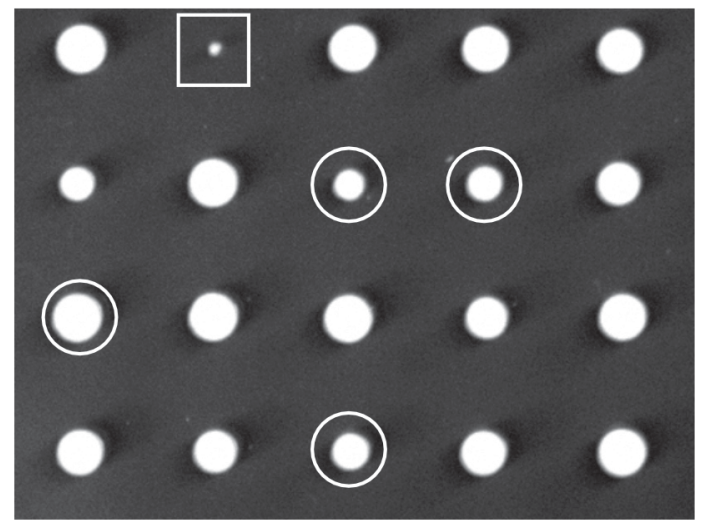

$\operatorname{rad50\Delta }$

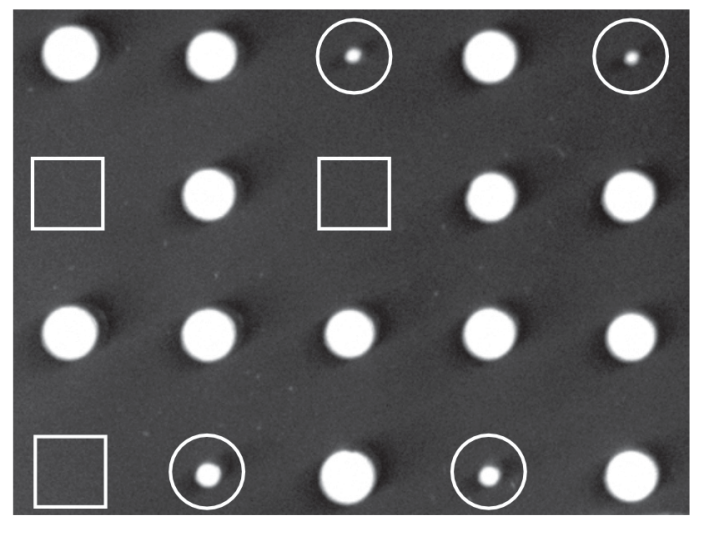

$\operatorname{sgs} 1 \Delta$

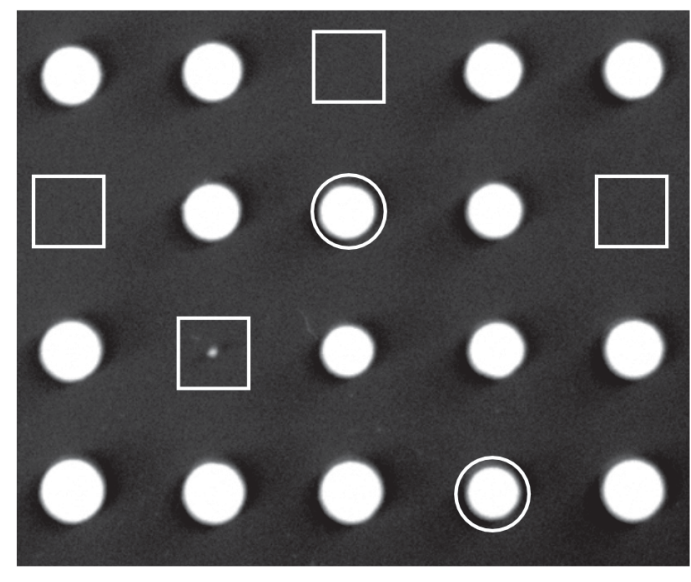

$r r m 3 \Delta$

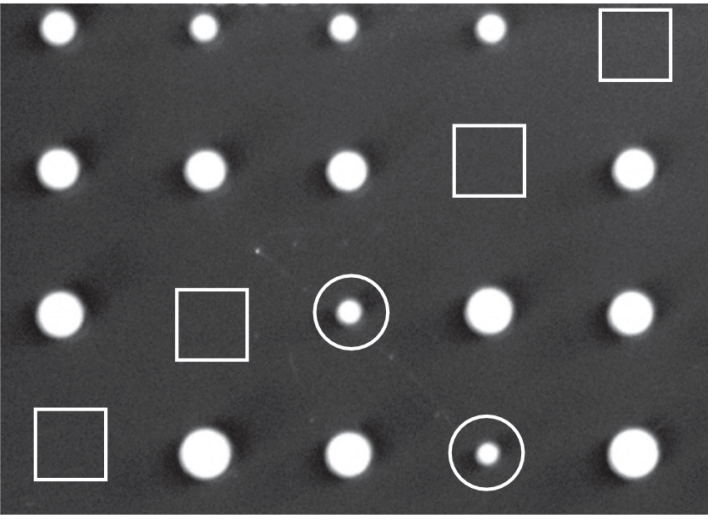

$\operatorname{rad} 54 \Delta$

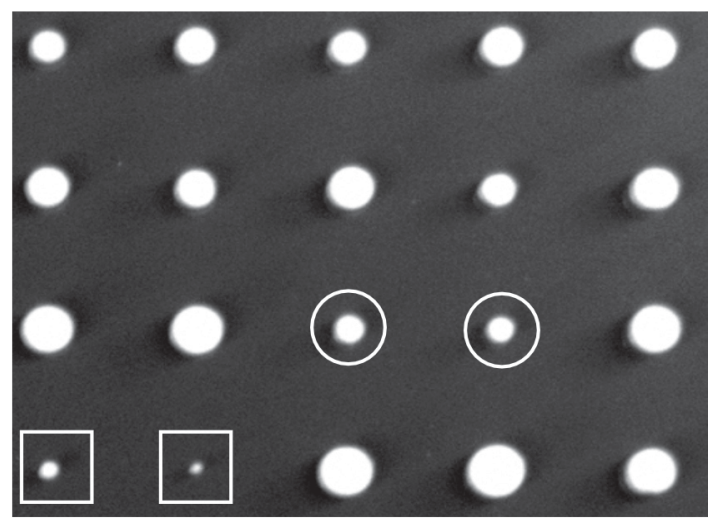

ctf18

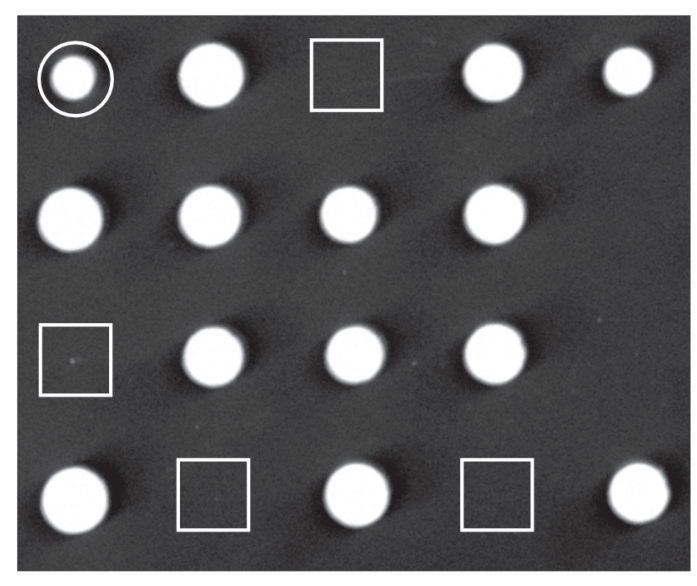

$\operatorname{mrc1\Delta }$

Ma et al. Figure S2 
Figure S3. Quantitative measurement of the impact of the V95I mutation on Rad52-selfinteraction by $\mathrm{Y} 2 \mathrm{H}$ analyses. Experiments were done in $\operatorname{rad} 52 \Delta$ cells to avoid the reduction of the Y2H signal by untagged Rad52. The median $\beta$-galactosidase activity is indicated (red line). Controls with empty vectors, pBTM116 (pB) or pACT2 (pA), are also shown. The V95I mutation does not affect Rad52-self-interaction. 
bioRxiv preprint doi: https://doi.org/10.1101/2021.05.18.444666; this version posted May 21, 2021. The copyright holder for this preprint (which was not certified by peer review) is the author/funder, who has granted bioRxiv a license to display the preprint in perpetuity. It is made available under aCC-BY-NC-ND 4.0 International license.

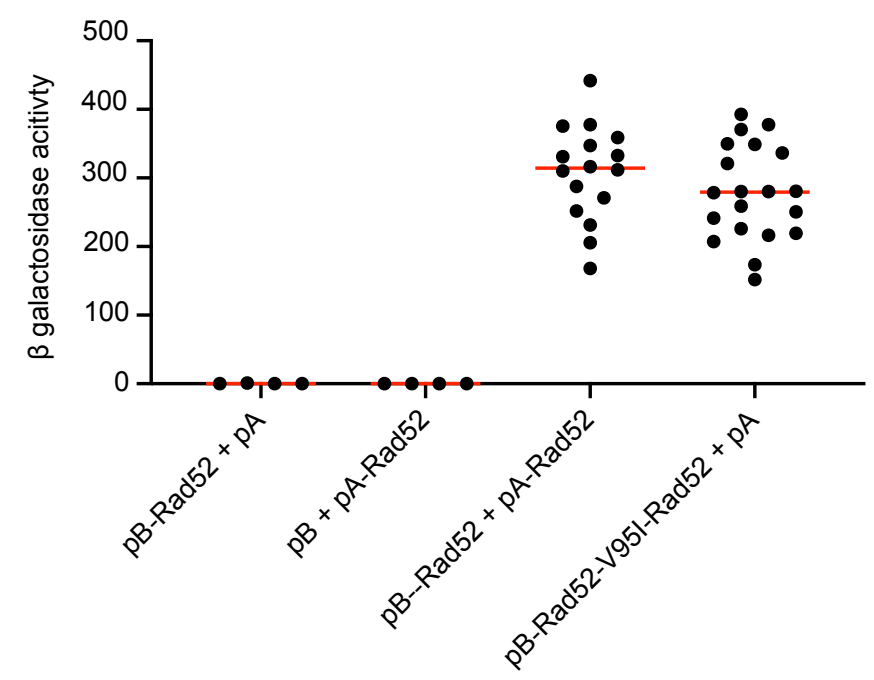

Ma et al. Figure S3 
bioRxiv preprint doi: https://doi.org/10.1101/2021.05.18.444666; this version posted May $21,2021$. The copyright holder for this preprint (which was not certified by peer review) is the author/funder, who has granted bioRxiv a license to display the preprint in perpetuity. It is made available under aCC-BY-NC-ND 4.0 International license.

Figure S4. Serial 10-fold dilutions of haploid strains with the indicated genotypes were spotted onto rich medium (YPD) containing different MMS concentrations. 
bioRxiv preprint doi: https://doi.org/10.1101/2021.05.18.444666; this version posted May 21, 2021. The copyright holder for this preprint (which was not certified by peer review) is the author/funder, who has granted bioRxiv a license to display the preprint in perpetuity. It is made available under aCC-BY-NC-ND 4.0 International license.
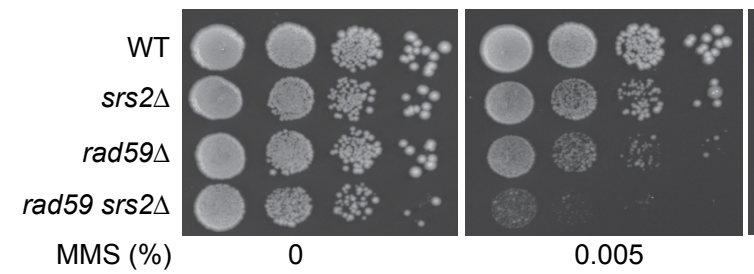

0.005

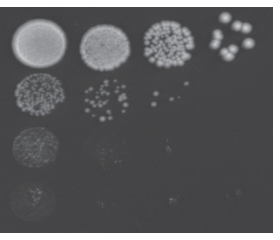

0.01

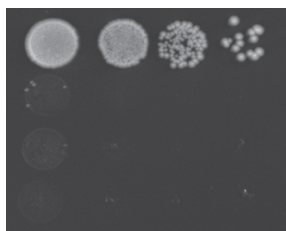

0.015

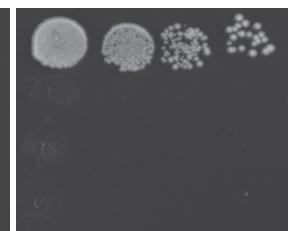

0.02

\section{Ma et al. Figure S4}


bioRxiv preprint doi: https://doi.org/10.1101/2021.05.18.444666; this version posted May 21,2021 . The copyright holder for this preprint

(which was not certified by peer review) is the author/funder, who has granted bioRxiv a license to display the preprint in perpetuity. It is made available under aCC-BY-NC-ND 4.0 International license.

Figure S5. Rad51 filament stability challenged with excess of ssDNA. All experiments were performed with FLAG-tagged Rad52 proteins. The addition of Rad52 or Rad52-V95I together with Rad51 to RPA-coated 400-nt-long ssDNA or 1500-nt-long ssDNA strongly catalyzes the formation of complete Rad51 filaments. Addition of increasing amounts of competitor $\Phi X 174$ ssDNA after Rad51 filament formation leads to their destabilization. Note the formation of an uncharacterized band with 1500-nt-long ssDNA (*). 
bioRxiv preprint doi: https://doi.org/10.1101/2021.05.18.444666; this version posted May 21, 2021. The copyright holder for this preprint

(which was not certified by peer review) is the author/funder, who has granted bioRxiv a license to display the preprint in perpetuity. It is made available under aCC-BY-NC-ND 4.0 International license.

\section{Complete Rad51}

filaments

RPA + Rad51

RPA + Rad51

Rad52

Rad52-V95I

ФX174 ( $\mu \mathrm{M} n$ t)

\begin{tabular}{lllllll}
\hline & + & + & + & + & + & \\
- & - & - & - & - & - &
\end{tabular}

Partial Rad51 + RPA -

filaments

400 nt-long ssDNA

1500 nt-long ssDNA

Ma et al. Figure S5 


\section{References}

1. Mehta, A. \& Haber, J. E. Sources of DNA double-strand breaks and models of recombinational DNA repair. Cold Spring Harb Perspect Biol 2014, 6. a016428.

2. Kowalczykowski, S. C. An Overview of the Molecular Mechanisms of Recombinational DNA Repair. Cold Spring Harb Perspect Biol 2015, 7.

3. Hunter, N. Meiotic Recombination: The Essence of Heredity. Cold Spring Harb Perspect Biol 2015, 7.

4. Zhang, J. M. \& Zou, L. Alternative lengthening of telomeres: from molecular mechanisms to therapeutic outlooks. Cell Biosci 2020, 10. 30.

5. Haber, J. E. DNA Repair: The Search for Homology. Bioessays 2018, 40. e1700229.

6. Guirouilh-Barbat, J., Lambert, S., Bertrand, P. \& Lopez, B. S. Is homologous recombination really an error-free process? Front Genet 2014, 5. 175.

7. Symington, L. S., Rothstein, R. \& Lisby, M. Mechanisms and regulation of mitotic recombination in Saccharomyces cerevisiae. Genetics 2014, 198. 795-835.

8. Spies, M. \& Fishel, R. Mismatch repair during homologous and homeologous recombination. Cold Spring Harb Perspect Biol 2015, 7. a022657.

9. Dupaigne, P., Le Breton, C., Fabre, F., Gangloff, S., Le Cam, E. \& Veaute, X. The Srs2 helicase activity is stimulated by Rad51 filaments on dsDNA: implications for crossover incidence during mitotic recombination. Mol Cell 2008, 29. 243-254.

10. Ira, G., Malkova, A., Liberi, G., Foiani, M. \& Haber, J. E. Srs2 and Sgs1-Top3 suppress crossovers during double-strand break repair in yeast. Cell 2003, 115. 401-411.

11. Mitchel, K., Lehner, K. \& Jinks-Robertson, S. Heteroduplex DNA position defines the roles of the Sgs1, Srs2, and Mph1 helicases in promoting distinct recombination outcomes. PLoS Genet 2013, 9. e1003340.

12. Mazon, G. \& Symington, L. S. Mph1 and Mus81-Mms4 prevent aberrant processing of mitotic recombination intermediates. Mol Cell 2013, 52. 63-74.

13. Prakash, R., Satory, D., Dray, E., Papusha, A., Scheller, J., Kramer, W., Krejci, L., Klein, H., Haber, J. E., Sung, P. \& Ira, G. Yeast Mph1 helicase dissociates Rad51-made D-loops: implications for crossover control in mitotic recombination. Genes Dev 2009, 23. 67-79.

14. Cejka, P., Plank, J. L., Bachrati, C. Z., Hickson, I. D. \& Kowalczykowski, S. C. Rmi1 stimulates decatenation of double Holliday junctions during dissolution by Sgs1-Top3. Nat Struct Mol Biol 2010, 17. 1377-1382.

15. Wu, L. \& Hickson, I. D. The Bloom's syndrome helicase suppresses crossing over during homologous recombination. Nature 2003, 426. 870-874.

16. Carver, A. \& Zhang, X. Rad51 filament dynamics and its antagonistic modulators. Semin Cell Dev Biol 2020,

17. Belan, O., Barroso, C., Kaczmarczyk, A., Anand, R., Federico, S., O’Reilly, N., Newton, M. D., Maeots, E., Enchev, R. I., Martinez-Perez, E., Rueda, D. S. \& Boulton, S. J. Single-molecule analysis reveals cooperative stimulation of Rad51 filament nucleation and growth by mediator proteins. Mol Cell 2021,

18. Candelli, A., Holthausen, J. T., Depken, M., Brouwer, I., Franker, M. A., Marchetti, M., Heller, I., Bernard, S., Garcin, E. B., Modesti, M., Wyman, C., Wuite, G. J. \& Peterman, E. J. Visualization and quantification of nascent RAD51 filament formation at singlemonomer resolution. Proc Natl Acad Sci U S A 2014,

19. Miné, J., Disseau, L., Takahashi, M., Cappello, G., Dutreix, M. \& Viovy, J. L. Real-time measurements of the nucleation, growth and dissociation of single Rad51-DNA nucleoprotein filaments. Nucleic Acids Res 2007, 35. 7171-7187. 
20. Qiu, Y., Antony, E., Doganay, S., Koh, H. R., Lohman, T. M. \& Myong, S. Srs2 prevents Rad51 filament formation by repetitive motion on DNA. Nat Commun 2013, 4. 2281.

21. Bonilla, B., Hengel, S. R., Grundy, M. K. \& Bernstein, K. A. $<\mathrm{i}>$ RAD51 $<$ i $>$ Gene Family Structure and Function. Annu Rev Genet 2020, 54. 25-46.

22. Bernstein, K. A., Reid, R. J., Sunjevaric, I., Demuth, K., Burgess, R. C. \& Rothstein, R. The Shu complex, which contains Rad51 paralogues, promotes DNA repair through inhibition of the Srs2 anti-recombinase. Mol Biol Cell 2011, 22. 1599-1607.

23. Burgess, R. C., Lisby, M., Altmannova, V., Krejci, L., Sung, P. \& Rothstein, R. Localization of recombination proteins and Srs2 reveals anti-recombinase function in vivo. J Cell Biol 2009, 185. 969-981.

24. Krejci, L., Van Komen, S., Li, Y., Villemain, J., Reddy, M. S., Klein, H., Ellenberger, T. \& Sung, P. DNA helicase Srs2 disrupts the Rad51 presynaptic filament. Nature 2003, 423. 305-309.

25. Liu, J., Renault, L., Veaute, X., Fabre, F., Stahlberg, H. \& Heyer, W. D. Rad51 paralogues Rad55-Rad57 balance the antirecombinase Srs2 in Rad51 filament formation. Nature 2011, 479. 245-248.

26. Ma, E., Dupaigne, P., Maloisel, L., Guerois, R., Le Cam, E. \& Coïc, E. Rad52-Rad51 association is essential to protect Rad51 filaments against Srs2, but facultative for filament formation. Elife 2018, 7.

27. Veaute, X., Jeusset, J., Soustelle, C., Kowalczykowski, S. C., Le Cam, E. \& Fabre, F. The Srs 2 helicase prevents recombination by disrupting Rad51 nucleoprotein filaments. Nature 2003, 423. 309-312.

28. Esta, A., Ma, E., Dupaigne, P., Maloisel, L., Guerois, R., Le Cam, E., Veaute, X. \& Coic, E. Rad52 Sumoylation Prevents the Toxicity of Unproductive Rad51 Filaments Independently of the Anti-Recombinase Srs2. PLoS Genet 2013, 9. e1003833.

29. Vasianovich, Y., Altmannova, V., Kotenko, O., Newton, M. D., Krejci, L. \& Makovets, $\mathrm{S}$. Unloading of homologous recombination factors is required for restoring doublestranded DNA at damage repair loci. EMBO J 2017, 36. 213-231.

30. Bergink, S., Ammon, T., Kern, M., Schermelleh, L., Leonhardt, H. \& Jentsch, S. Role of Cdc48/p97 as a SUMO-targeted segregase curbing Rad51-Rad52 interaction. Nat Cell Biol 2013, 15. 526-532.

31. Mortensen, U. H., Bendixen, C., Sunjevaric, I. \& Rothstein, R. DNA strand annealing is promoted by the yeast Rad52 protein. Proc Natl Acad Sci U S A 1996, 93. 10729-10734.

32. Seong, C., Sehorn, M. G., Plate, I., Shi, I., Song, B., Chi, P., Mortensen, U., Sung, P. \& Krejci, L. Molecular anatomy of the recombination mediator function of Saccharomyces cerevisiae Rad52. J Biol Chem 2008, 283. 12166-12174.

33. Kagawa, W., Kurumizaka, H., Ishitani, R., Fukai, S., Nureki, O., Shibata, T. \& Yokoyama, S. Crystal structure of the homologous-pairing domain from the human Rad52 recombinase in the undecameric form. Mol Cell 2002, 10. 359-371.

34. Ranatunga, W., Jackson, D., Lloyd, J. A., Forget, A. L., Knight, K. L. \& Borgstahl, G. E. Human RAD52 exhibits two modes of self-association. J Biol Chem 2001, 276. 15876-15880.

35. Shinohara, A., Shinohara, M., Ohta, T., Matsuda, S. \& Ogawa, T. Rad52 forms ring structures and co-operates with RPA in single-strand DNA annealing. Genes Cells 1998, 3. $145-156$.

36. Singleton, M. R., Wentzell, L. M., Liu, Y., West, S. C. \& Wigley, D. B. Structure of the single-strand annealing domain of human RAD52 protein. Proc Natl Acad Sci US A 2002, 99. 13492-13497. 
37. Stasiak, A. Z., Larquet, E., Stasiak, A., Muller, S., Engel, A., Van Dyck, E., West, S. C. \& Egelman, E. H. The human Rad52 protein exists as a heptameric ring. Curr Biol 2000, 10. 337-340.

38. Mortensen, U. H., Erdeniz, N., Feng, Q. \& Rothstein, R. A molecular genetic dissection of the evolutionarily conserved $\mathrm{N}$ terminus of yeast Rad52. Genetics 2002, 161. 549562.

39. Shi, I., Hallwyl, S. C., Seong, C., Mortensen, U., Rothstein, R. \& Sung, P. Role of the Rad52 amino-terminal DNA binding activity in DNA strand capture in homologous recombination. J Biol Chem 2009, 284. 33275-33284.

40. Heude, M. \& Fabre, F. a/alpha-control of DNA repair in the yeast Saccharomyces cerevisiae: genetic and physiological aspects. Genetics 1993, 133. 489-498.

41. Lovett, S. T. \& Mortimer, R. K. Characterization of null mutants of the RAD55 gene of Saccharomyces cerevisiae: effects of temperature, osmotic strength and mating type. Genetics 1987, 116. 547-553.

42. Mozlin, A. M., Fung, C. W. \& Symington, L. S. Role of the Saccharomyces cerevisiae Rad51 paralogs in sister chromatid recombination. Genetics 2008, 178. 113-126.

43. Vaze, M. B., Pellicioli, A., Lee, S. E., Ira, G., Liberi, G., Arbel-Eden, A., Foiani, M. \& Haber, J. E. Recovery from checkpoint-mediated arrest after repair of a double-strand break requires Srs2 helicase. Mol Cell 2002, 10. 373-385.

44. Elango, R., Sheng, Z., Jackson, J., DeCata, J., Ibrahim, Y., Pham, N. T., Liang, D. H., Sakofsky, C. J., Vindigni, A., Lobachev, K. S., Ira, G. \& Malkova, A. Break-induced replication promotes formation of lethal joint molecules dissolved by Srs2. Nat Commun 2017, 8. 1790.

45. Saotome, M., Saito, K., Yasuda, T., Ohtomo, H., Sugiyama, S., Nishimura, Y., Kurumizaka, H. \& Kagawa, W. Structural Basis of Homology-Directed DNA Repair Mediated by RAD52. iScience 2018, 3. 50-62.

46. Ventura, S., Vega, M. C., Lacroix, E., Angrand, I., Spagnolo, L. \& Serrano, L. Conformational strain in the hydrophobic core and its implications for protein folding and design. Nat Struct Biol 2002, 9. 485-493.

47. Wu, Y., Kantake, N., Sugiyama, T. \& Kowalczykowski, S. C. Rad51 protein controls Rad52-mediated DNA annealing. J Biol Chem 2008, 283. 14883-14892.

48. Davis, A. P. \& Symington, L. S. The yeast recombinational repair protein Rad59 interacts with Rad52 and stimulates single-strand annealing. Genetics 2001, 159. 515525.

49. Wu, Y., Sugiyama, T. \& Kowalczykowski, S. C. DNA annealing mediated by Rad52 and Rad59 proteins. J Biol Chem 2006, 281. 15441-15449.

50. Sugawara, N., Ira, G. \& Haber, J. E. DNA length dependence of the single-strand annealing pathway and the role of Saccharomyces cerevisiae RAD59 in double-strand break repair. Mol Cell Biol 2000, 20. 5300-5309.

51. Bai, Y. \& Symington, L. S. A Rad52 homolog is required for RAD51-independent mitotic recombination in Saccharomyces cerevisiae. Genes Dev 1996, 10. 2025-2037.

52. Kolesar, P., Altmannova, V., Silva, S., Lisby, M. \& Krejci, L. Pro-recombination role of Srs2 requires SUMO but is independent of PCNA interaction. J Biol Chem 2016,

53. San Filippo, J., Sung, P. \& Klein, H. Mechanism of eukaryotic homologous recombination. Annu Rev Biochem 2008, 77. 229-257.

54. Broomfield, S. \& Xiao, W. Suppression of genetic defects within the RAD6 pathway by srs2 is specific for error-free post-replication repair but not for damage-induced mutagenesis. Nucleic Acids Res 2002, 30. 732-739. 
55. Pfander, B., Moldovan, G. L., Sacher, M., Hoege, C. \& Jentsch, S. SUMO-modified PCNA recruits Srs2 to prevent recombination during S phase. Nature 2005, 436. 428433.

56. Gaines, W. A., Godin, S. K., Kabbinavar, F. F., Rao, T., VanDemark, A. P., Sung, P. \& Bernstein, K. A. Promotion of presynaptic filament assembly by the ensemble of S. cerevisiae Rad51 paralogues with Rad52. Nat Commun 2015, 6. 7834.

57. Hansson, M. D., Rzeznicka, K., Rosenback, M., Hansson, M. \& Sirijovski, N. PCRmediated deletion of plasmid DNA. Anal Biochem 2008, 375. 373-375.

58. Altschul, S. F., Madden, T. L., Schaffer, A. A., Zhang, J., Zhang, Z., Miller, W. \& Lipman, D. J. Gapped BLAST and PSI-BLAST: a new generation of protein database search programs. Nucleic Acids Res 1997, 25. 3389-3402.

59. Schaffer, A. A., Aravind, L., Madden, T. L., Shavirin, S., Spouge, J. L., Wolf, Y. I., Koonin, E. V. \& Altschul, S. F. Improving the accuracy of PSI-BLAST protein database searches with composition-based statistics and other refinements. Nucleic Acids Res 2001, 29. 2994-3005.

60. Katoh, K. \& Standley, D. M. MAFFT multiple sequence alignment software version 7: improvements in performance and usability. Mol Biol Evol 2013, 30. 772-780.

61. Waterhouse, A. M., Procter, J. B., Martin, D. M., Clamp, M. \& Barton, G. J. Jalview Version 2--a multiple sequence alignment editor and analysis workbench.

Bioinformatics 2009, 25. 1189-1191.

62. Waterhouse, A., Bertoni, M., Bienert, S., Studer, G., Tauriello, G., Gumienny, R., Heer, F. T., de Beer, T. A. P., Rempfer, C., Bordoli, L., Lepore, R. \& Schwede, T. SWISSMODEL: homology modelling of protein structures and complexes. Nucleic Acids Res 2018, 46. W296-W303.

63. Pupko, T., Bell, R. E., Mayrose, I., Glaser, F. \& Ben-Tal, N. Rate4Site: an algorithmic tool for the identification of functional regions in proteins by surface mapping of evolutionary determinants within their homologues. Bioinformatics 2002, 18 Suppl 1. S71-7.

64. Strahl-Bolsinger, S., Hecht, A., Luo, K. \& Grunstein, M. SIR2 and SIR4 interactions differ in core and extended telomeric heterochromatin in yeast. Genes Dev 1997, 11. 8393.

65. Li, M. Z. \& Elledge, S. J. Harnessing homologous recombination in vitro to generate recombinant DNA via SLIC. Nat Methods 2007, 4. 251-256. 